A. Pflitsch, E. Cartaya, B. McGregor, D. Holmgren, and B. Steinhöfel. Climatologic studles inside Sandy Glacier at Mount Hood Volcano in Oregon, USA. Journal of Cave and Karst Studies, v. 79, no. 3, p. 189-206. DOI: 10.4311/2015IC0135

\title{
CLIMATOLOGIC STUDIES INSIDE SANDY GLACIER AT MOUNT HOOD VOLCANO IN OREGON, USA
}

\author{
Andreas Pflitsch ${ }^{1}, 4$, , Eddy Cartaya ${ }^{2}$, Brent McGregor ${ }^{3}$, David Holmgren ${ }^{1}$, and Björn Steinhöfel ${ }^{5}$
}

\begin{abstract}
Previous investigations of climatic conditions of glaciers primarily focused on the glacier's surface or on the moulin as the entrance to the glacier's interior. Many glaciers, however, contain far-reaching cave systems inside the ice that have been understood and investigated as drainage systems for meltwater. Until now, there have been no comprehensive climate studies inside a glacier cave. Thus, the climatic conditions, as well as their effects on the glacier, are unknown. The first climatologic investigations inside the cave system of Sandy Glacier on Mt. Hood in Oregon (USA) in June 2015 have shown that both thermic activity of the volcanic subsurface and chimney effects between the glacier snout at the base of the glacier and higher opening of the moulin can cause drastic melting inside the glacier. Those processes lead to considerably stronger melting from the inside than observations at the surface suggest and can cause an unexpected collapse over a distance of several hundred meters. We will present and assess the first measuring results of both the thermic and flow conditions inside Sandy Glacier.
\end{abstract}

\section{Introduction}

The research field of glaciology includes numerous disciplines. Studies provide extensive knowledge of the formation and the decay of glaciers, their characteristics and movement, and their impact on the underlying landscape, as well as records of historical and recent conditions (Barry and Gan, 2011; Benn and Evans, 2010; Singh et al., 2011). The relationship between glaciers and climatic events is also the subject of numerous investigations. Interaction between air temperature, precipitation, and the conditions of glaciers are well studied (Alean, 2010; Aizen, 2011). Furthermore, glaciers are recognized as important archives of climate records (Sigl et al., 2016; Rhodes et al., 2016; Bourne et al., 2015; Blockley et al., 2014) and have been the subject of hydrological studies on, inside, and beneath glaciers (Andrews et al., 2014; Fountain et al., 2005; Greenwood et al., 2016; Unterfrauner, 2009). Moulins start as vertical conduits that channel water from supraglacial water courses to the bedrock of the glacier and are part of the hydrological system (Holmlund, 1988). While this may be the primary function early in their development, it has to be questioned for their further evolution. Bhutiyani's (2011) short chapter about "Ice Caves" also points out that the caves evolve from meltwater channels or by rising heat of an underlying volcano.

The term ice cave, while frequently used to describe caves in ice, is correctly associated with natural bedrock caves formed entirely in rock, inside of which reside seasonal or perennial ice packs, floors, lakes, etc. (Barry and Gan, 2011). Glacier caves, by comparison, are formed inside the ice mass of a glacier or ice plug, either by water, air convection due to air pressure, temperature or density gradients, venturi effects, geothermal activity, sublimation, glacier movement and fracturing, or a combination of several mechanisms (Benn and Evans, 2010, Badino et al., 2007). The passages either occur at the contact of the ice and the underlying bedrock (contact caves), within the ice pack itself, or consist entirely of ice passages (englacial caves). Plastic deformation of the glacier also works in concert with these forces to either lengthen, close, or reshape the passages. Because both systems develop and function differently, we recommend a strict distinction of the two terms to avoid any misunderstanding

The effects of volcanic eruptions on glaciers has been studied intensely, especially for Mount St. Helens (Brugman and Post, 1998). Unfortunately, the influence of the weather outside the glacier, especially temperature, humidity, and wind conditions, to the air mass inside glaciers, which are important for internal melting or sublimation processes, has not been subject of research or intensively described to date.

Considering the spectrum of glacier research, it is surprising that there are only a few articles and no real investigations on the relationship between the subglacial air mass and glacial ice-the meteorology and climatology of glacier caves-despite the fact that glacial caves, also referred as subglacial or englacial meltwater channels or drainage systems (Greenwood et al., 2016, Vihma, 2011) may contain both air and water. The first and only available information about airflow in glacial conduits is from 1835. The description of Gletschergeblaese, which translates as "small openings with exhaling air out of a glacier." is more or less the explanation of the typical chimney effects of moulins and en-

\footnotetext{
${ }^{1}$ Department of Geography, Ruhr-Universität Bochum, Bochum, GERMANY

${ }^{2}$ National Cave Rescue Commission Coordinator, Pacific Northwest / National Speleological Society, Redmond, Oregon, USA

${ }^{3}$ Oregon High Desert Grotto Chairman, Sisters, Oregon, USA

${ }^{4}$ Department of Geographie, Humboldt Universität zu Berlin GERMANY

5Urbannstr. 12, 35216 Biedenkopf, GERMANY

cCorresponding Author: andreas.pflitsch@rub.de
} 
trances (v. Leonhard, 1835). Reported 172 years earlier, this first description is already close to Schroeder (2007), who describes a moulin as "a thermal anomaly of subpolar glaciers." Although the article focuses on moulins as drainages for water and important factors for the circulation of intra- and subglacial meltwater, Schroeder presents a very detailed model about the impact of air inflow and trapped air inside a moulin during the different seasons and the importance of airflow for stabilizing the moulin covering snow bridges. He describes the interaction of ice, water, and air inside the moulin in comparison to airflow and convective processes. Even though the conditions found in the glacial caves on Mt. Hood are different, he gives some information about the interaction between water, ice, and air masses.

The lack of research in glacial caves could be related to the difficulties in making long-term measurements in an extremely dynamic environment with constant changes in cave morphology. The number and structure of entrances also changes constantly, and the potential for loss of instrumentation must be taken into account, even for a twelve-month period. The accessibility of the caves, the instability of the entrances and interiors, and the extensive amount of gear needed for a safe multiple-day expedition also make these studies difficult, and caving inside glaciers is dangerous in general (Benn and Evans, 2010), with experience in ice climbing and ropework necessary to doing this research.

While the shaping power of water is clearly visible in supraglacial channels, moulins, and englacial and subglacial conduits (Benn and Evans 2010; Holmlund 1988, Sudgen and John 1976), the effect of air currents is much more difficult to ascertain and not yet discussed or identified as an important key factor for the glacial energy and mass balance.

Looking into a moulin from the surface of a glacier, one can already see the formative power of water. A wild, rushing glacial stream visibly demonstrates the erosive capability and power of water, especially when loaded with sediments. Because of diurnal and seasonal air temperature changes, meltwater rates are constantly changing. Meltwater discharge peaks during the summer, and the lowest meltwater flow occur in winter or early morning (Schroeder 2007; Ben and Evans 2010).

Air currents inside a glacier cave, on the other hand, are not always noticeable. They can be too weak to feel or just flowing under the ceiling without being evident at the ground. Their direct impact on the ice can only be seen by means of shell-shaped patterns in the walls of the cave, the so called scallops. Scallops formed in rocks are usually related to flowing water (Gunn, 2004; Lauritzen, 1981). In ice they also develop under the influence of airflow (Pflitsch et al., 2016). Their positions all over the walls and the ceiling of the glacier cave clearly show the development of the scallops just by airflow, which underlines the importance of atmospheric climate studies inside glaciers.

When Fountain $(2011$, p. 258) states that ". . . the term generally implies that portion of the ice body which is not directly affected by the atmosphere. In this view, the englacial region starts below average crevass depth from the

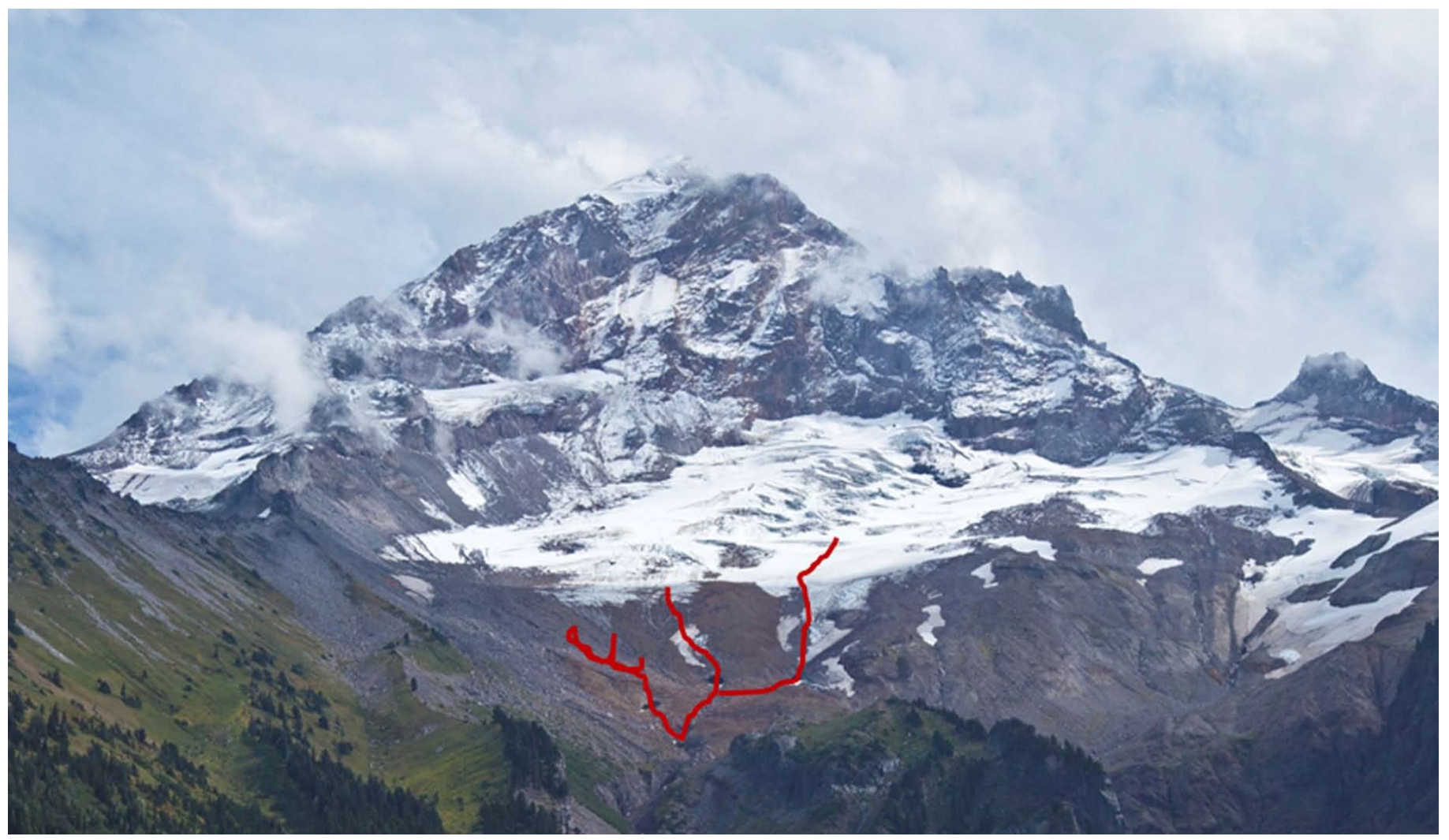

Figure 1. Mt. Hood, Oregon, with the Sandy Glacier in 2013. The red lines show the location of the Snow Dragon Glacier Cave System. 
atmosphere-ice interface." This might be correct for huge ice sheets, but has to be reconsidered for smaller glaciers or the edges of ice sheets. However, for the moulins and glacier caves, the larger the passage dimensions, the more substantial the influence of the atmosphere and the convective air inside the glacier caves becomes. At first glance, it appears the conduit development is chiefly controlled by water flow and sometimes cracks, in fact, the airflow through the system plays a much more important role in the morphology of the system, and in the subglacial ice mass balance (ablation) the bigger the conduits get in diameter. The conduits are not chiefly hydrological, but rather, chiefly conduits of air currents that have much more effect on the subglacial ice mass. So the moulin becomes more and more a part of a ventilation system of air currents inside the whole cave system.

An expedition to the Sandy Glacier on Mount Hood from June 21 to June 25, 2015, was the beginning to closing this research gap. The goals of the expedition included the spatial and temporal measurement of climatic conditions inside the glacier cave and the confirmation of first measurements from previous expeditions. Before the comprehensive data set will be analyzed completely and future research will give us a much better idea of climatic conditions and related processes, this article presents the first and most important results of the climatological investigations in two glacier caves on Mount Hood in Oregon, USA. These first results already show how the climatology within glacier caves can impact the characteristics of a glacier. We provide evidence that glaciers do not only melt from the outside, but that under certain circumstances glacial melting can also quickly progress from the inside.

The structure of the cave, and especially the effect of warm springs originating from volcanoes, were identified as important influencing factors on the impact of internal air masses. The large dimension made possible by volcanic activity influencing glacial caves was mentioned, but not measured, previously by Badino et al. (2007) when he described the large network of cave passages for the Paradise Ice Caves of Mt. Rainier (46.8159 $\left.\mathrm{N}, 121.7165^{\circ} \mathrm{W}\right)$, which have melted down at a high rate already, as well as glacial caves in Iceland and the Arctic. That means large glacier caves are known at different places over the world. Besides the initial influence of the hot water or water vapor, no further climatic research has been done.

Even though necessary calculations, like melting rates and ice mass loss, cannot be presented right now, it is important to introduce the new field of "climatology of glacial caves" as soon as possible for further research, because it's an additional factor we have to take into account for glacier melting and retreat.

\section{Short Introduction to Glacial Research at Mt. Hood Before Starting Intensive Climate Mea- surements}

The Sandy Glacier on Mount Hood is located on the northwestern side of Oregon's largest mountain and less than $96 \mathrm{~km}$ from Portland, Oregon. The glacier was visited 31 times between June 6, 2011, and October, 2015. The goals were to survey, observe, and measure several glacier caves, with special focus on the changes of the glacier and its caves. Three of those visits were expeditions during which scientists investigated the glacier over a period of several days. The expeditions were July 6-14, 2012, July 13-21, 2013, and June 20-25, 2015.

Figure 1 shows the glacier in summer 2013; the red lines show the location of the Snow Dragon Cave System. The lower cave entrance is located at approximately 1950 meters above sea level. The upper end is close to 2250 meters above sea level.

The first two expeditions focused on surveying the glacier caves, as well as measuring climate data such as air temperature, air moisture, and air current in Pure Imagination Cave. We also collected rock, sediment and biomass oil-like samples along with collections of invertebrates, fir tree seedlings, feathers, and leaves.

Those measurements were first presented at the International Workshop on Ice Caves in Idaho Falls (Idaho, USA) in August 2014 and led to a lively discussion. Because the relatively high air temperatures of $7{ }^{\circ} \mathrm{C}$ inside the glacier cave were generally doubted, we decided to record the climatic conditions with a high temporal and spatial resolution during a subsequent expedition.

Besides the various measurements, photographs were taken during each visit to record any visible changes of the glacier. Unfortunately, a direct comparison of those photographs proved to be difficult due to varying snow cover and sites caused by the retreat of the glacier. The following selection of pictures demonstrates changes of Sandy Glacier between 2011 and 2015.

Figures 2 and 3 show the Sandy Glacier in 2012 and in 2015 with all visible cave entrances of the cave system. The retreat of the glacial entrances or collapsed cave parts are well visible. The entrances have been melting and collapsing up-glacier at a fast rate over the short period of observation.

During our five-year study from 2010 to 2015 we have observed cave ceiling heights and widths becoming larger. Figures 4 and 5 show the entrance areas of Pure Imagination Cave. Due to the best stability of the cave and the safest conditions, we intensified our investigation in Pure Imagination Cave, especially the climatologic research. Figure 4 shows the entrance and Figure 5 the crawl into the cave at its discovery on October 10, 2011. Thick firn layers above the glacier ice had kept the cave hidden until the 2011 summer melt. 


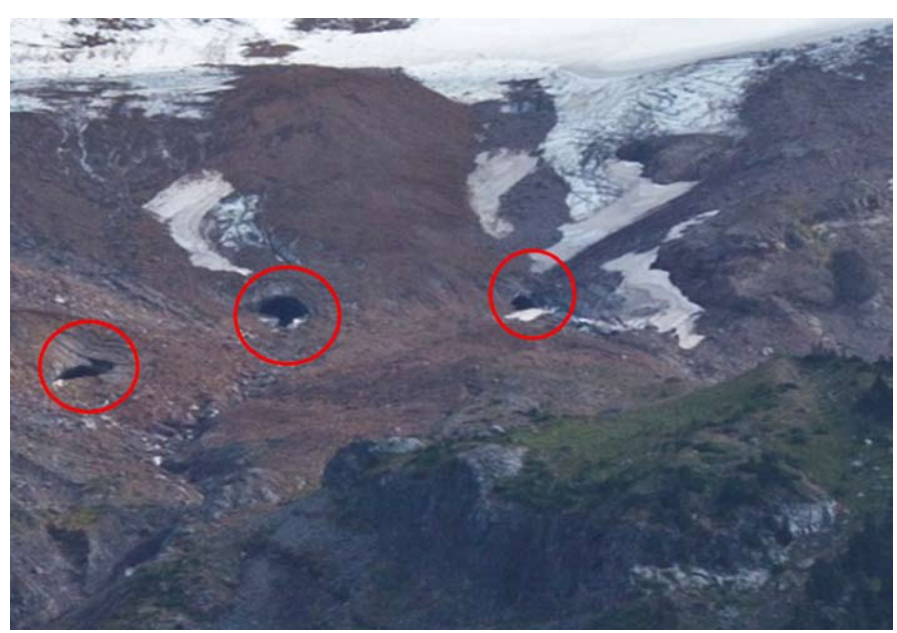

Figure 2. Close-up of the cave entrances of Sandy Glacier in summer of 2013. All three cave entrances (Frozen Minotaur, left; Snow Dragon, middle; Pure Imagination, right) are visible.

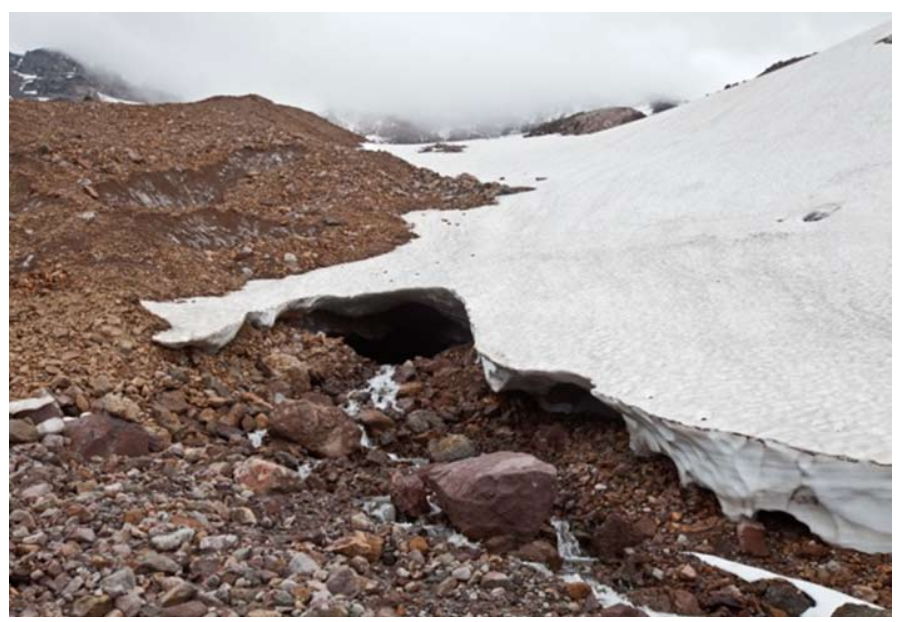

Figure 4. Entrance of Pure Imagination Cave during discovery on October 20, 2011.

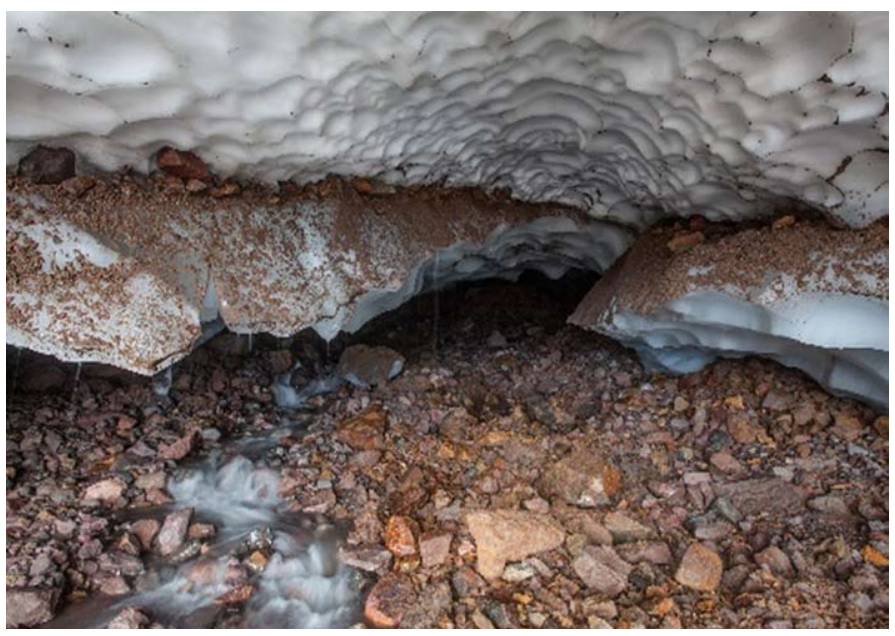

Figure 5. Pure Imagination Cave on day of discovery required crawling to get inside the cave, about $0.6 \mathrm{~m}$ high and 3 to $4 \mathrm{~m}$ wide.

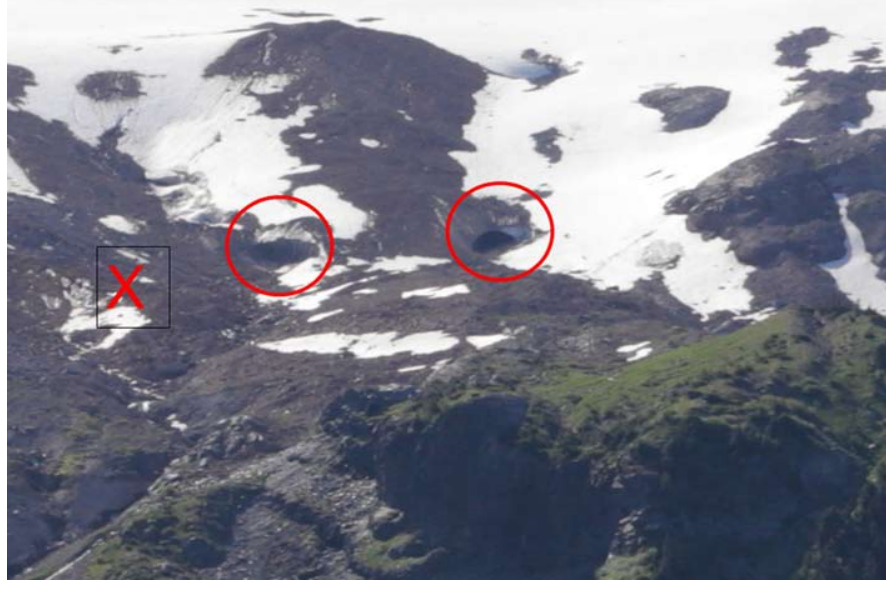

Figure 3. Close-up of the cave entrances of Sandy Glacier in summer of 2015. Frozen Minotaur has collapsed, left; the upper part of Snow Dragon in the middle has collapsed while the retreated entrance is still intact; Pure Imagination on the right has retreated but still in good condition.

The first complete map of the Snow Dragon Glacier Cave System is shown in Figure 6. The total length in 2011-12 was $2184 \mathrm{~m}$, and the vertical extent was $292 \mathrm{~m}$.

Figures 7 and 8 showing the most recent entrance of Pure Imagination Cave were taken in June and October 2015. The entrance has moved $137 \mathrm{~m}$ above the location of the originally discovered cave entrance. The entrance changed from $0.6 \mathrm{~m}$ high and $3 \mathrm{~m}$ wide to about $4 \mathrm{~m}$ high and $15 \mathrm{~m}$ wide. This part of the cave lost so much of its length that it's possible to see the entrance to the moulin above (Fig. 8).

The Cerberus Moulin located in the middle of Pure Imagination Cave has increased in size at an alarming rate (Figs. 9 and 10). In 2012, the moulin had an air volume of about $2300 \mathrm{~m} 3$. In 2013 we measured a volume of $9600 \mathrm{m3}$.

Figure 9 shows ice over 30 meters deep, and Figure 10 shows ice thickness less than one meter at the same location. Due to changes occurring in a three-year span, one can observe the floor of the cave easily with the pile of collapsed ceiling. Figures 11 and 12, both views of the of inside of Cerebus Moulin, show that the overburden has greatly reduced in thickness.

The analysis of the extensive photographic material of the past years reveals that the glacier does not only decrease in length at the glacier front and in thickness at the surface, but also melts off from the inside at great speed, and therefore, loses mass. The latter was surprising and should be further investigated.

\section{Short- and Long-Term Measuring Program Inside Sandy Glacier}

The climatological measuring program was started on October 10, 2014, by the installation of the first sensors and was expanded by mobile measurements, as well as the installation of additional sensors in $\mathbf{2 0 1 5}$ for the entire area of the caves (Fig. 13). The measuring program can 
Figure 6. Map of the cave system (Frozen Minotaur, Snow Dragon, and Pure Imagination) inside the Sandy Glacier of $\mathrm{Mt}$. Hood in 2013.

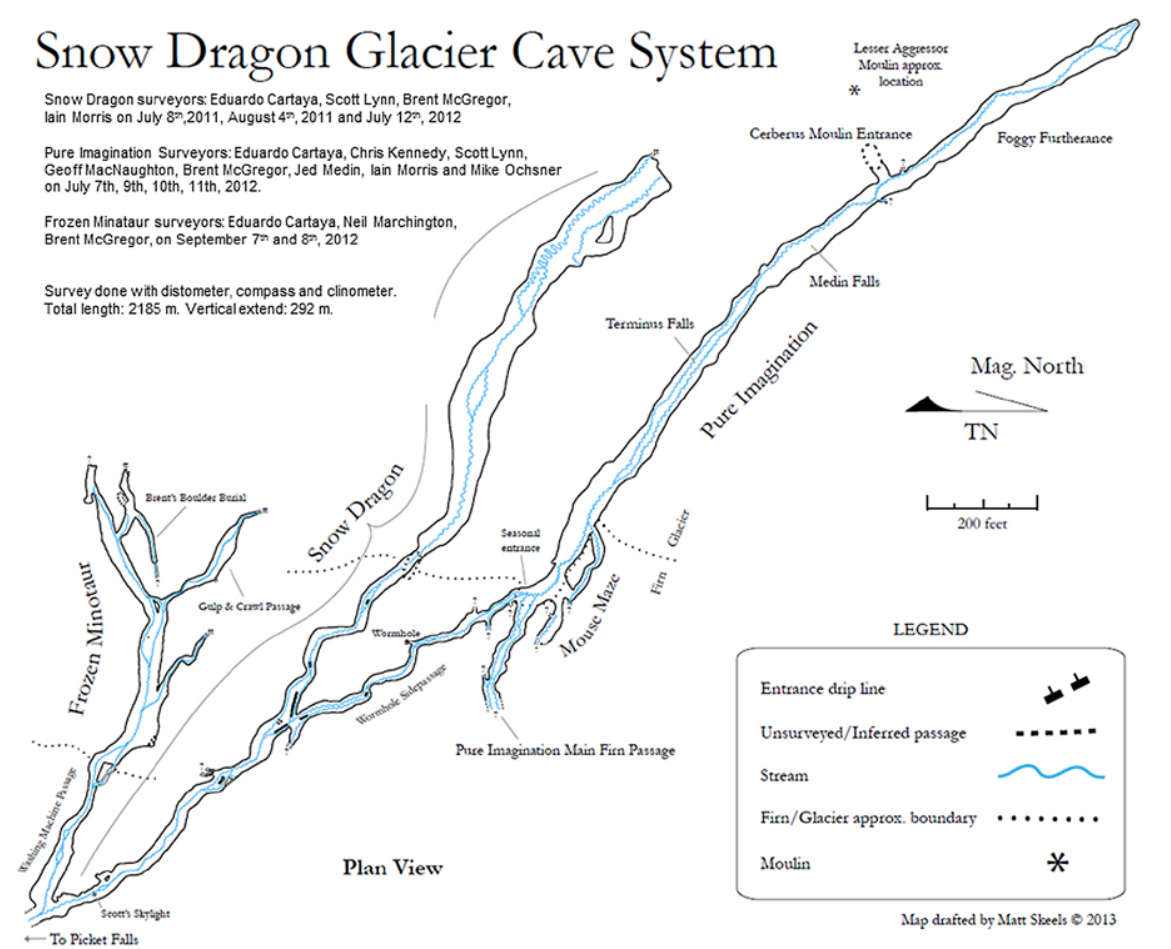

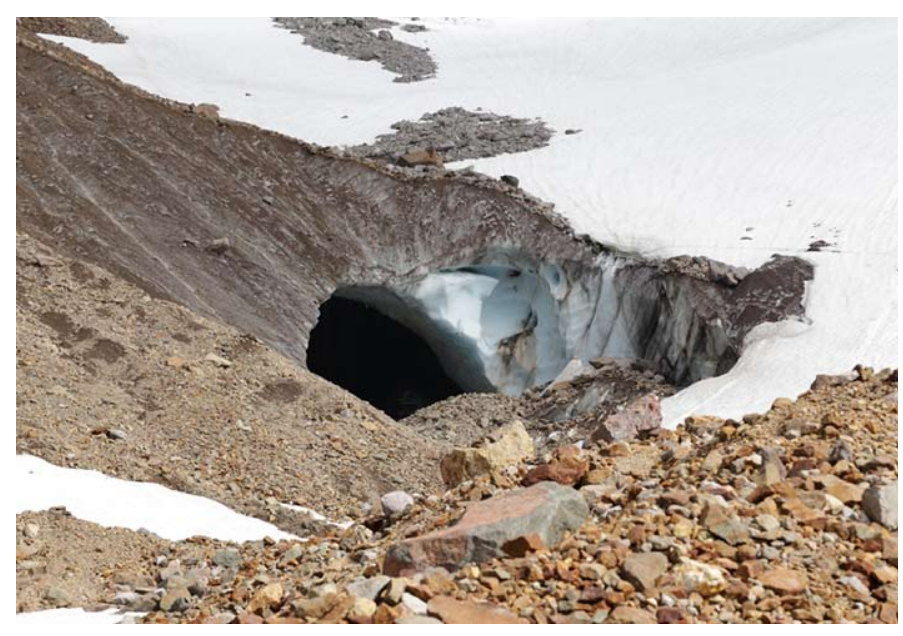

Figure 7. Lower entrance to Pure Imagination Cave on June 22, .2015. The entrance has increased in size $4 \mathrm{~m}$ high and $15 \mathrm{~m}$ wide.

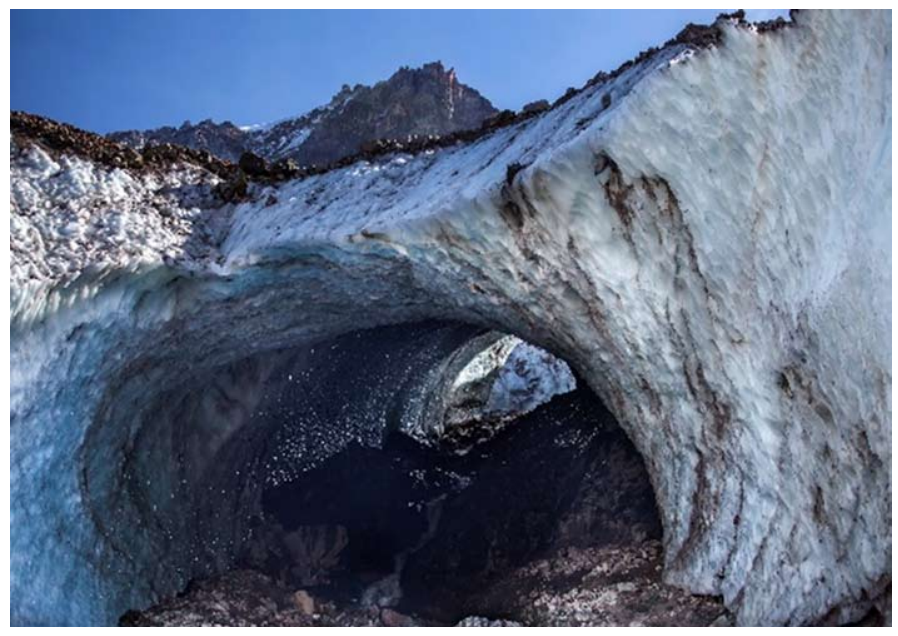

Figure 8. Remnant entrance of Pure Imagination Cave on October 10, 2015. Light from Cerberus Moulin shows through the upper end of the cave.

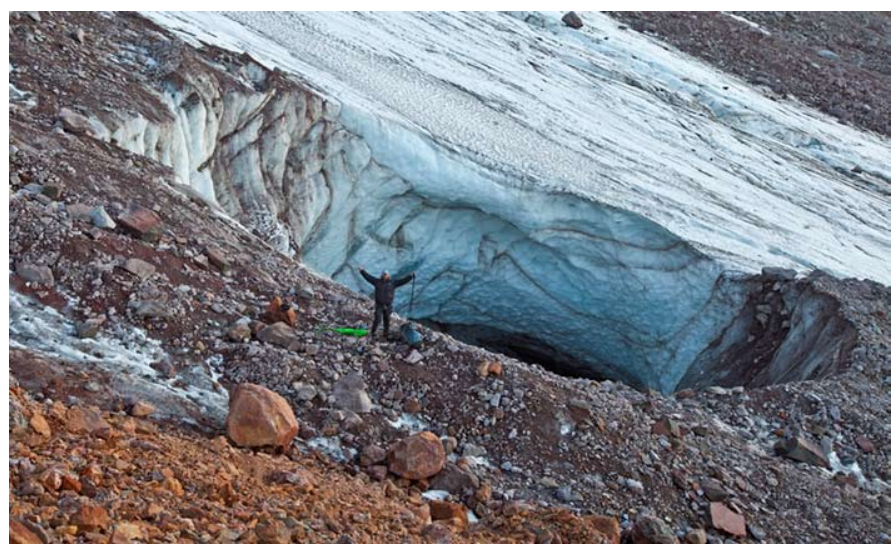

Figure 9. The Cerberus Moulin, Pure Imagination Cave on September 19, 2013. 


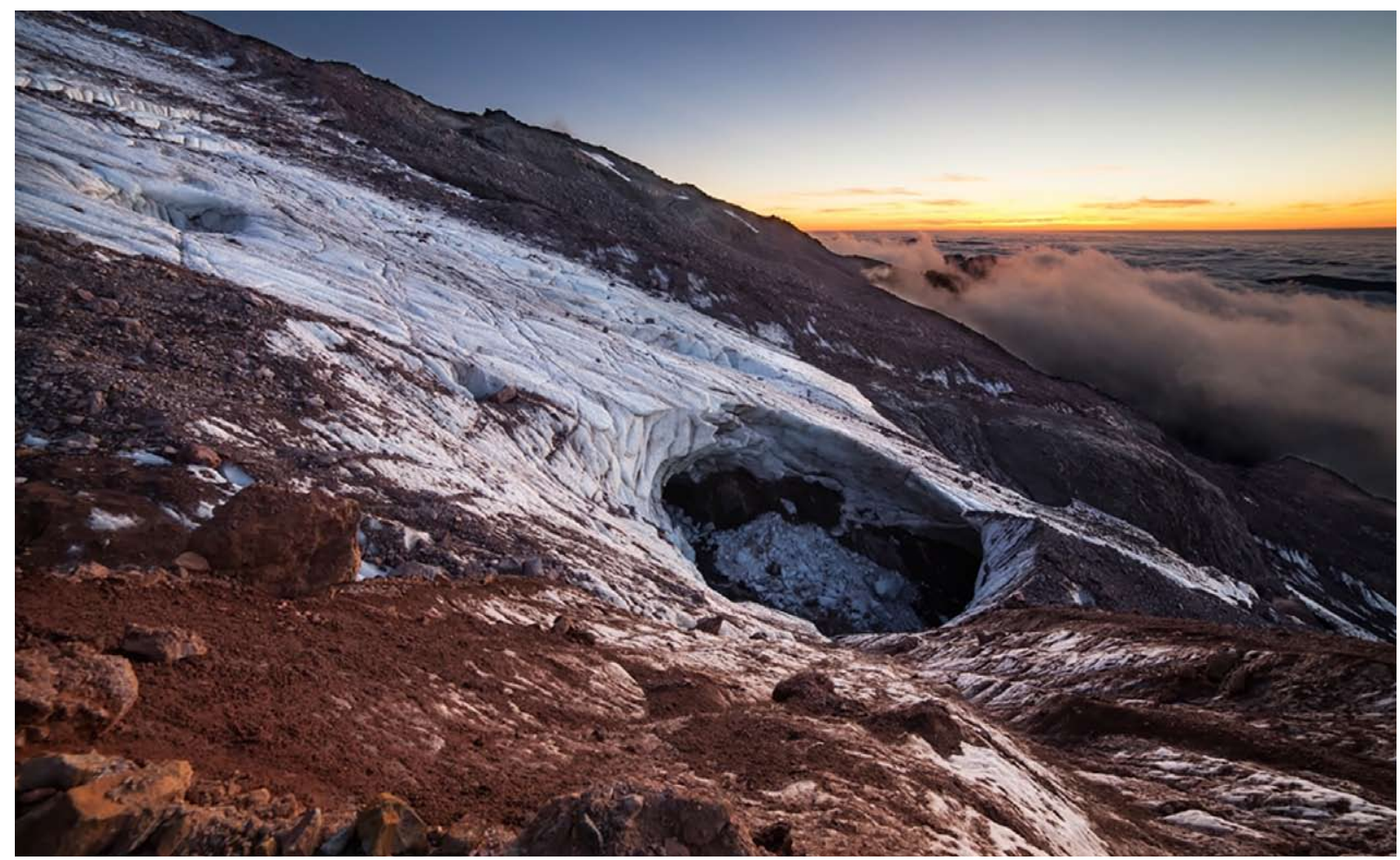

Figure 10. Cerberus Moulin, Pure Imagination Cave on June 20, 2015. The old moulin has increased in size dramatically.

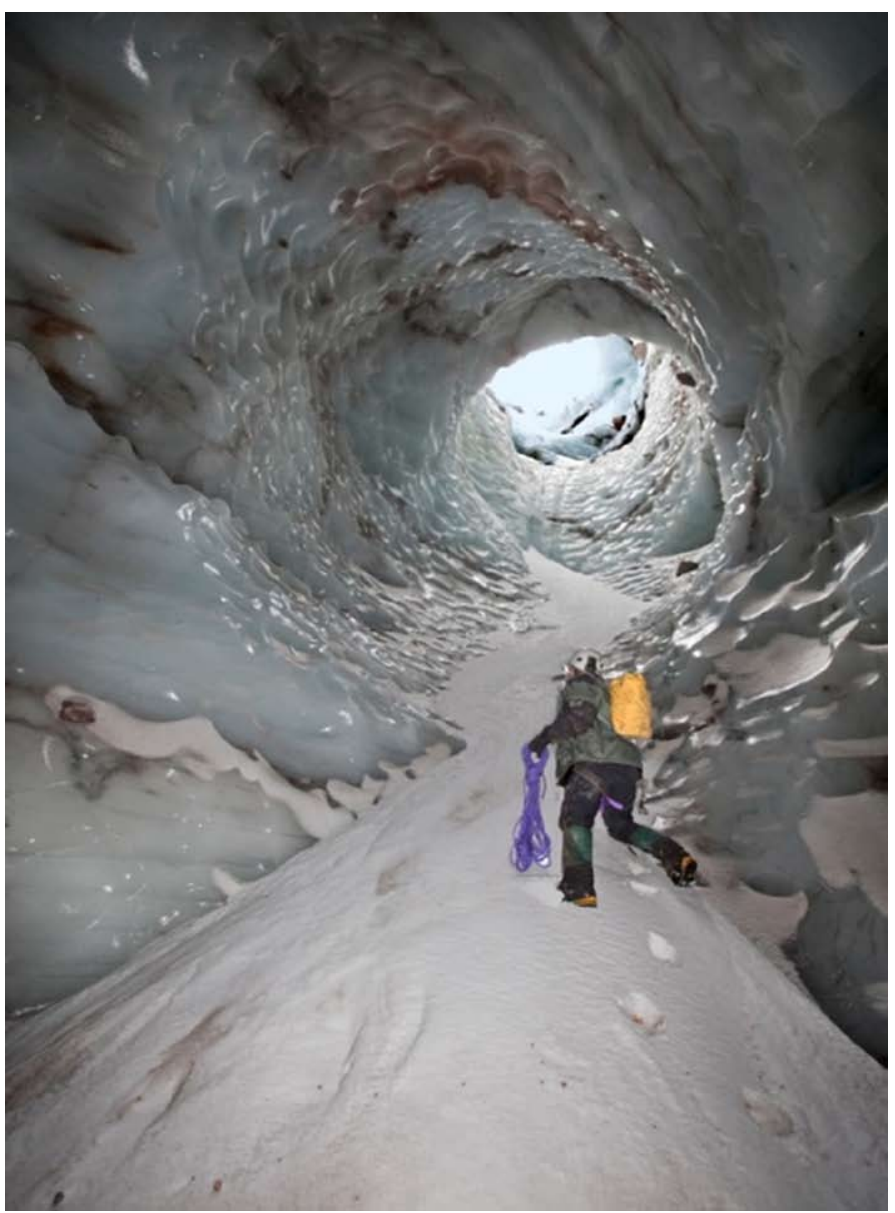

Figure 11. Cerberus Moulin the day of discovery on November 9, 2011. View from the inside looking out the moulin.

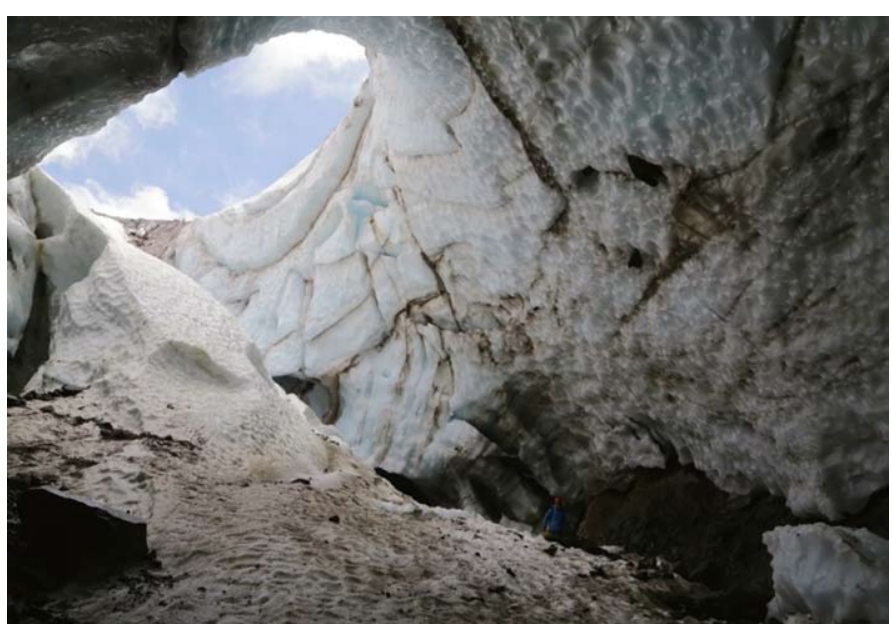

Figure 12. Cerberus Moulin on June 22, 2015. View from the inside out the moulin. 


\section{Pure Imagination Cave}

Surveyed by Eduardo Cartaya, Chris Kennedy, Scott Lynn, Geoff MacNaughton, Brent McGregor, Jed Medin, lain Morris and Mike Ochsner on July 7th, 9th, 10th, 11th, 2012. Survey done with distometer, compass and clinometer.

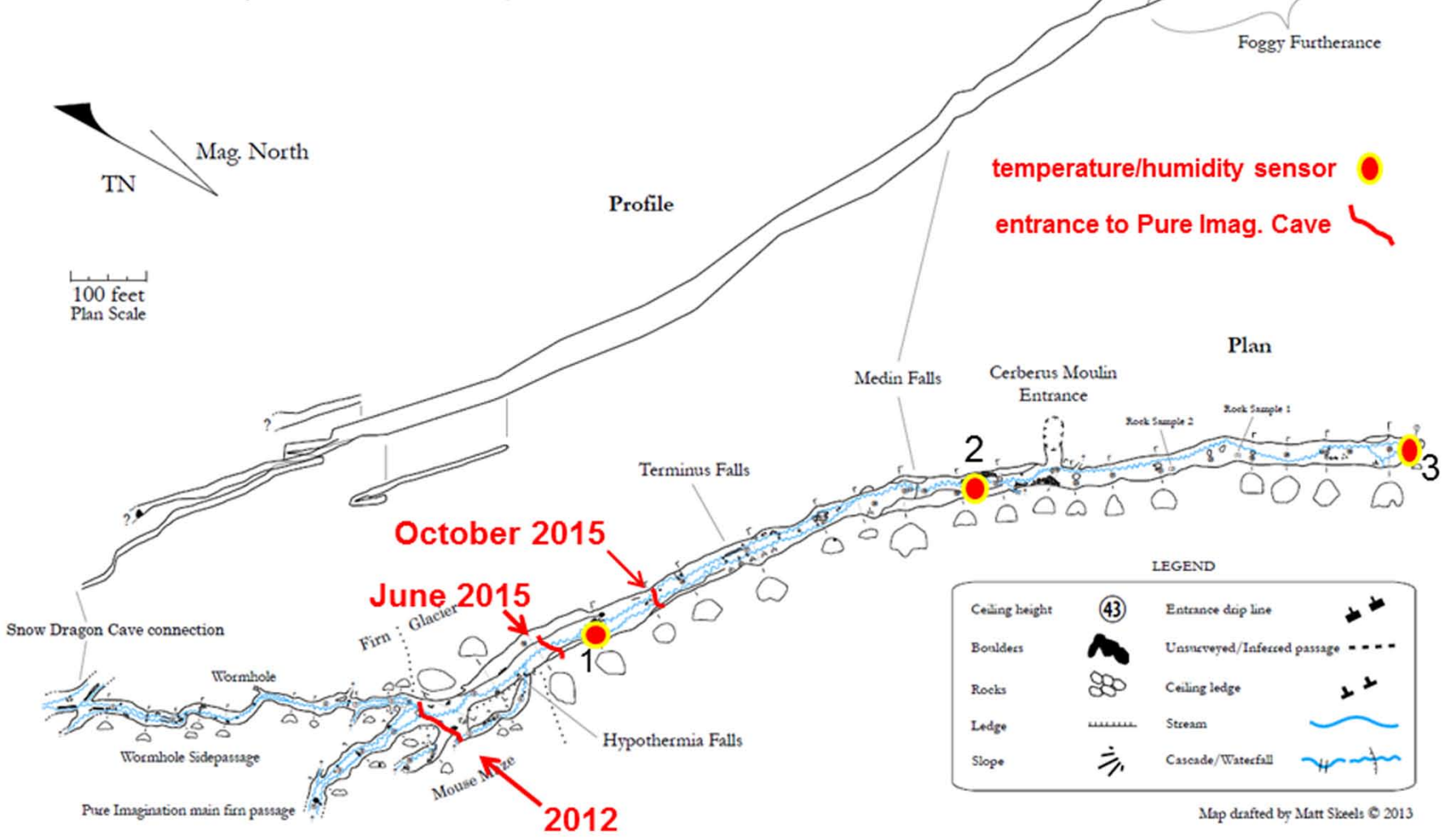

Figure 13. Map of Pure Imagination Cave showing changes of the cave entrance and the placement of the first data loggers in 2014.

be subdivided into the following stages: On October 10, 2014, we set up of a stationary installation of three sensors to measure air temperature and relative air moisture inside the glacier cave. From June 20-25, 2015, we undertook an intensive, short-term mobile measuring program to measure air, water, and surface temperatures throughout the entire area of the cave, as well as to measure air currents at two sites, above and below the moulin. For a clearer identification, we call the lower part of the cave Pure Imagination and the upper part beyond the moulin Hot Imagination Cave. On June 25, 2015, we expanded the measuring network by four additional measuring sensors to measure air and water temperatures inside Hot Imagination Cave.

\section{Start of Long-Time Measurements}

The first monitoring network was installed to gain a preliminary impression of the climatic conditions inside the glacier cave as a basis for following measurements in spring 2015. The goal was to install temperature and humidity sensors with data loggers for storing the data before the winter season to get an overview of the entire area of the cave. After the first visit, we decided to leave the sensors for at least three years or as long as the caves exist. Sensor 1 (GEOPRECISION M-Log5W-HUMIDITY data logger for air humidity and air temperature in white plastic housing; filter cap: HD-polyethylene, porous diameter $25 \mu \mathrm{m}$; sensor type: Sensirion SHT75; accuracy air humidity: $\pm 1.8 \%$; accuracy air temperature: $\pm-0.3^{\circ} \mathrm{C}$ ) was positioned at the lower entrance of the glacier close to the former exit. Sensor 2 was installed about $20 \mathrm{~m}$ below the large moulin at the end of Pure Imagination Cave, while sensor 3 was installed at the upper end of Hot Imagination Cave. Thus, two sensors were located in areas influenced by openings, while sensor 3 was located at the closed upper end. The sensors were positioned to be protected from falling rocks as well as from dripping water. The measuring frequency was 30 minutes.

\section{Mobile Measurements and Short-Time Measurements Program}

The mobile measuring program from June 20 to June 25, 2015 covered two priority areas. Both flow conditions at two selected sites in a vertical profile and thermal conditions in a high spatial resolution were obtained.

Repeated mobile measurements of air temperature, as well as of flow velocity and direction every $20 \mathrm{~m}$ throughout 


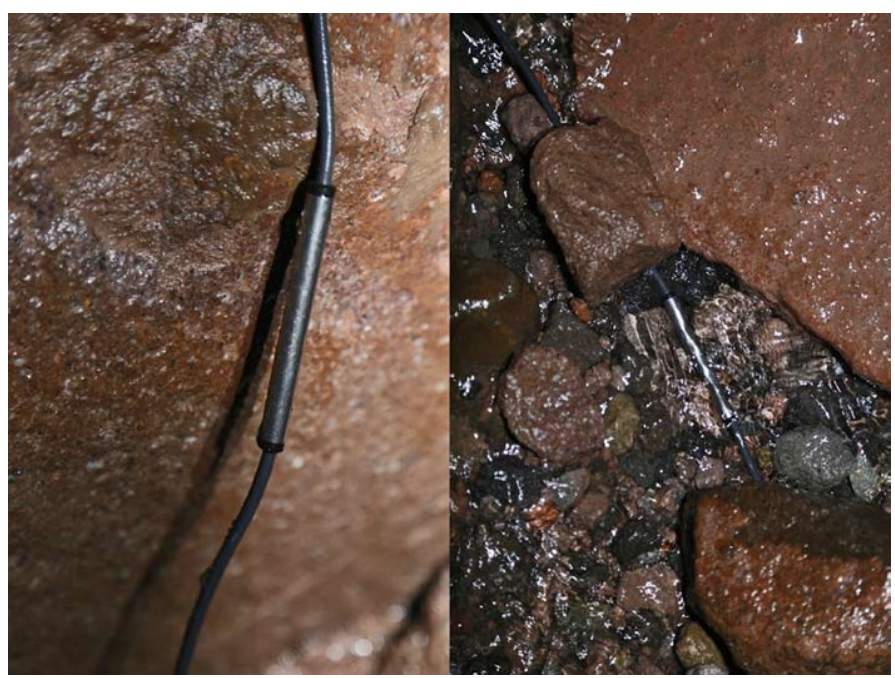

Figure 14. Sensors of the sensor chain of 28 sensors measuring the air and water temperature in Hot Imagination Cave.

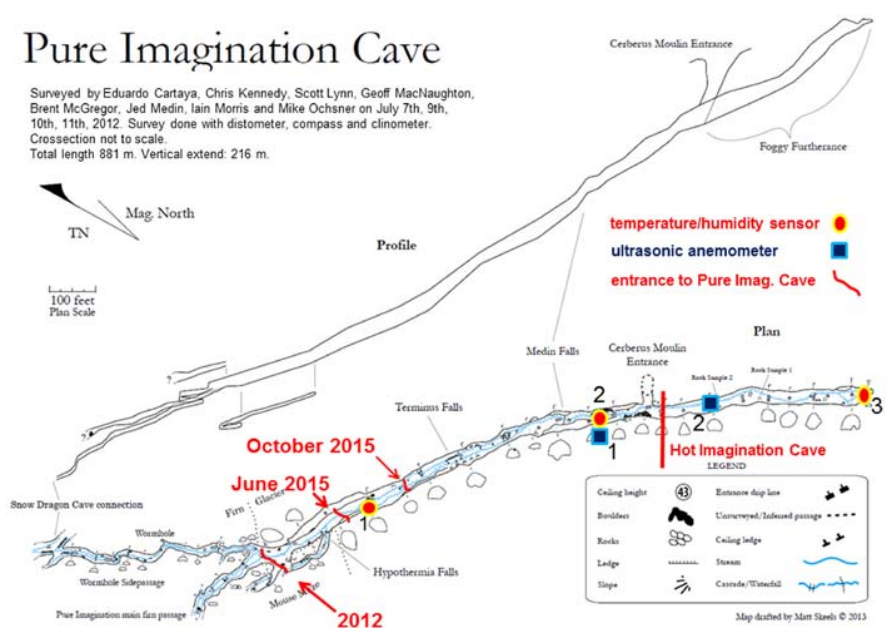

Figure 15. Pure Imagination Cave showing the location of the ultrasonic anemometers in comparison of the location of the data loggers.

the entire cave, were taken at $0.05 \mathrm{~m}$ above ground and $2.0 \mathrm{~m}$ above ground with a Testo 925 .

Repeated mobile measurements of surface temperature with a thermal camera (InfraTec VarioCAM) in the entire cave at intervals of 10 to $20 \mathrm{~m}$ over the entire length of the cave each up- and down-glacier. Consistent intervals were not possible due to the complex topography of the cave.

Measurements of air and water temperature at selected sites were obtained using a sensor chain (GEOPRECISION digital thermistor string; resolution: $0.065{ }^{\circ} \mathrm{C}$; accuracy (typical): $\pm 0.25^{\circ} \mathrm{C}$ for the range $-10{ }^{\circ} \mathrm{C}$ to $+30^{\circ} \mathrm{C}$; string cable in PUR quality; the string is absolutely waterproof / IP69; diameter: cable $5 \mathrm{~mm} /$ sensor: $8 \mathrm{~mm}$ ) of $30 \mathrm{~m}$ length with 28 temperature sensors at intervals of $1 \mathrm{~m}$ (Fig. 14), from June 21 9:45 p.m. to June 23 00:00 midnight. The sensor chains were installed in the higher part of the cave, starting from the warmest spring known so far. Three further warm spring areas (so-called hotspots), mixing areas, and cold-water runoffs were also recognized. Unfortunately, meltwater leaving the ice could not be surveyed due to distance.

Stationary measurement of air temperature, as well as horizontal and vertical air currents, were collected at heights of 0.6 and $4 \mathrm{~m}$ above ground at two sites (Figs. 15 to 17) using ultrasonic anemometers (METEK USA 1). Site 1 is located in Hot Imagination Cave about $20 \mathrm{~m}$ behind the opening to the moulin. In this area, the slope gradient is low, about 5 degrees. The lower measuring instrument was placed in the meltwaters flowing out about $0.6 \mathrm{~m}$ above ground ,and therefore, was located about $6 \mathrm{~m}$ lower than the measuring instrument close to the ceiling. Site 2 was located in Pure Imagination Cave about $20 \mathrm{~m}$ behind the opening to the moulin at a steep slope of about 25 degrees. The measuring instrument close to the ground was placed in the lower part of the slope directly above the meltwater stream, and the higher measuring instrument was located in the central area of the slope, about $4 \mathrm{~m}$ above the ground and $8 \mathrm{~m}$ above the lower measuring instrument. The upper anemometer malfunctioned after 12:47 hours.

\section{Long-Term Measurements}

Based on the mobile measuring program, four additional temperature sensors with data loggers were installed (GEOPRECISION M-Log5W-CABLE temperature data logger with sensor cable in waterproof plastic housing; sensor type: PT1000 in stainless steel cap; accuracy: $\pm 0.1^{\circ} \mathrm{C}$ (at $0^{\circ} \mathrm{C}$ ); resolution: $0.01^{\circ} \mathrm{C}$.) on June 25,2015 (Fig. 18). This campaign focused on water temperatures in the hottest known spring in Hot Imagination Cave, as well as in the outlet area about $20 \mathrm{~m}$ from the large moulin. In addition, temperature sensors were placed $1 \mathrm{~m}$ above ground in the central hall at the latter site and at the same height directly next to the ice wall. The investigations focused on thermal dynamics between the lower end close to the opening of the cave and the closed upper end. These measurements are scheduled at least for 3 more years or until collapse of the cave.

\section{Summary of First Results}

The first expedition focusing on the climatology of glacier caves revealed numerous unexpected results.

\section{Stationary Measurements of Air Temperature Using Data Loggers}

Preliminary measurements in 2014 showed an unusually high air temperature of up to $7{ }^{\circ} \mathrm{C}$; especially in areas upglacier from the Cerberus Moulin of the glacier cave. In general, we expect air temperatures around the freezing point, as the air temperature inside glacier caves is influenced by the surrounding ice masses, meltwater flow, and potentially 
Figure 16. Location of the ultrasonic anemometers in Pure Imagination Cave. Left: view to the lower entrance of the cave. Right: view to the upper entrance (Cerebus Moulin) cave

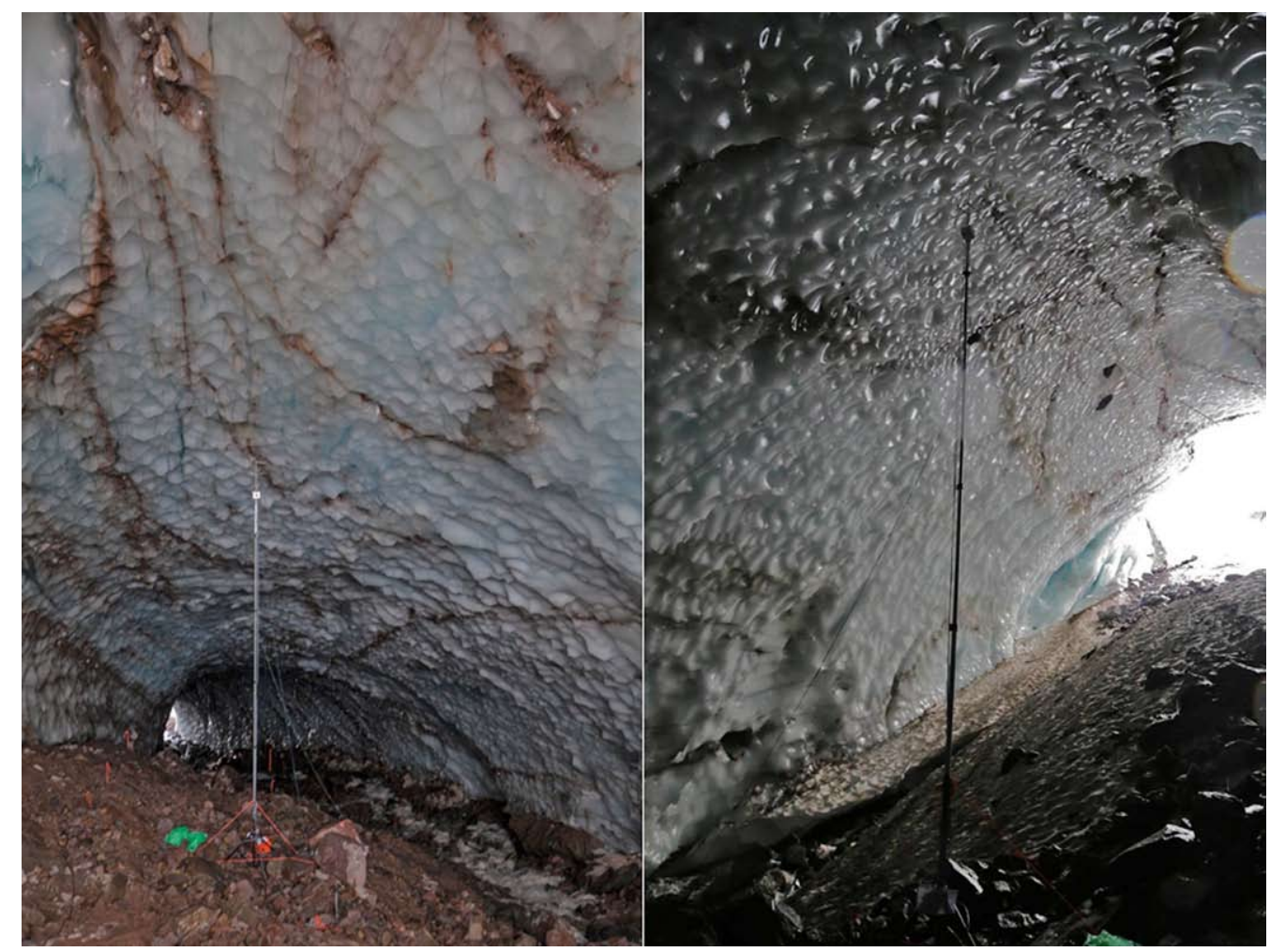

Figure 17. Location of the ultrasonic anemometers in Hot Imagination Cave. View out of the cave in upper picture, view inside cave in lower picture.

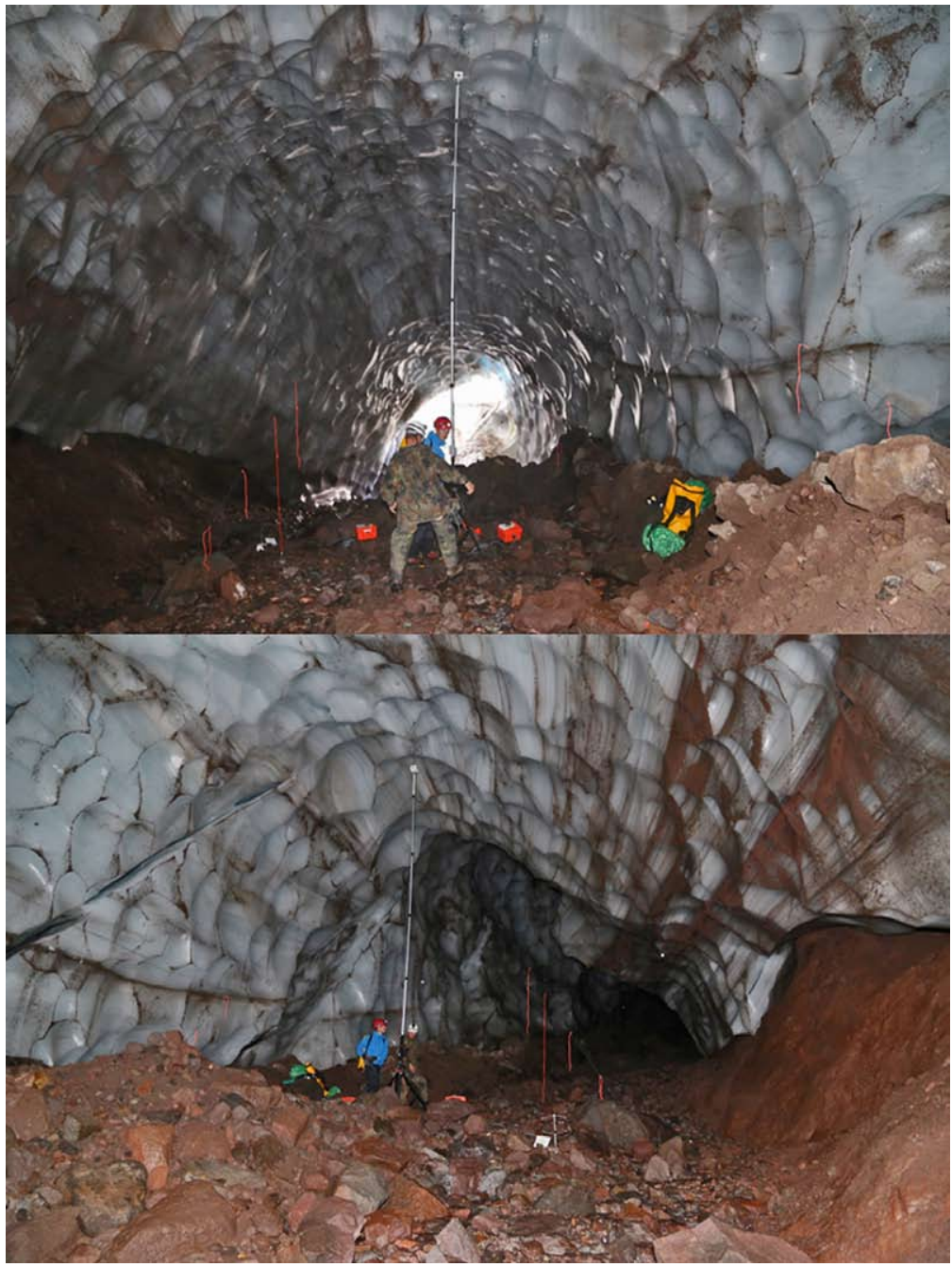




\section{Hot Imagination Cave}

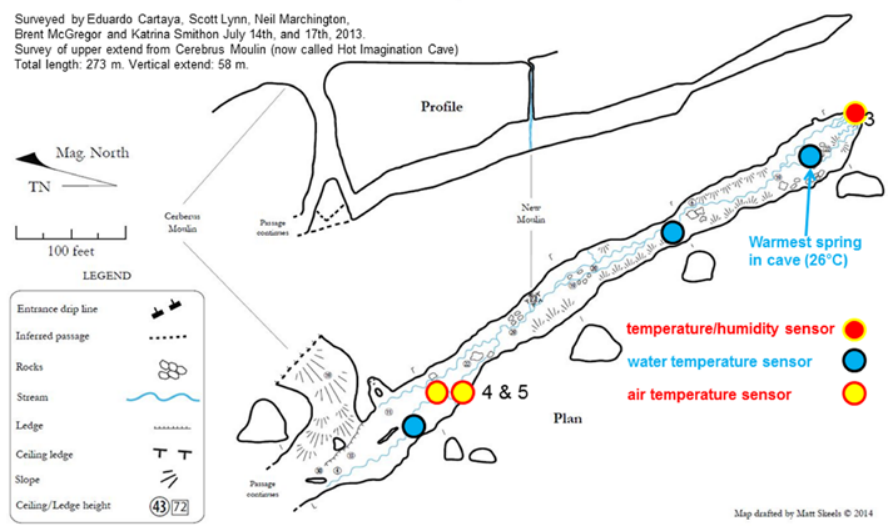

Figure 18. Pure Imagination Cave placement of additional data loggers.

the exposed bedrock and boulders. Generally, considerably higher or lower air temperatures can only occur in the entrance area of the cave or open moulins due to inflowing warm or cold air from the outside atmosphere. The first measurements, however, also showed surprisingly high air temperatures at the closed upper end of the cave, even in winter (Fig. 19, sensor 3). Additionally, dense fog already indicated special conditions in this area (Fig. 20).

Comparing the data from three temperature sensors reveals substantial differences between the sites. The air temperature at both sites inside Pure Imagination Cave (Fig. 19, sensors 1 and 2) are more or less similar until November 2014 . They are clearly influenced by atmospheric air, showing drops in temperature, along with warmer periods. In contrast, the sites that were located up-glacier inside the conduit were slightly cooler. This may be due to higher elevation up-glacier or cold inflowing air from the moulin only 20 m away. Later, the higher site (Fig. 19, sensor 2) still showed substantial temperature fluctuations, while the temperature at site 1 had little to no fluctuations. The sensor may have been covered in snow starting in November, which it shielded from the atmospheric influences. This, however, is not visible till February for the higher site close to the moulin (Fig. 19, sensor 2) due to its more sheltered position in the cave. Here some snow blown inside might have damped the temperature from the middle of February to the beginning of June. Even in June, sensor 1 was still covered in snow and fallen ice and could not be found. Due to the remote sensor we could download the data, but the data are not representative of air temperature (Fig. 19).

Air temperature at sensor 3 at the upper end of Hot Imagination Cave (i.e., the sensor farthest from the entrance) shows a completely different pattern. Due to its position at the very end of the cave in the area of outflowing meltwater discharge between glacial ice and bedrock and its large distance from the cave's openings, stable air temperatures around freezing point are expected. In addition, no incoming warm air masses are expected, at least during the winter months. Against these expectations, air temperature do not drop below freezing at any time, but varies between 2.8 and $3.5^{\circ} \mathrm{C}$. Remarkably, a wave structure characterized by abrupt drops in air temperature and slow temperature increases was found; its frequency decreased from 6 to 17 days in fall 2014 up to 2 months in spring 2015. One possible reason is outbreaks of cold meltwater from the upper part of the glacier, which are more likely in fall than in winter and early spring. This could explain the temperature drop and the changing frequency.

The highest temperature of $3.6^{\circ} \mathrm{C}$ was reached on March 15, 2015 and steadily decreased afterward, followed by some intense temperature drops. Even during the most intense drop in air temperature, it only drops once below $1^{\circ} \mathrm{C}$ for a short time. Those high air temperatures can be considered as an anomaly. 


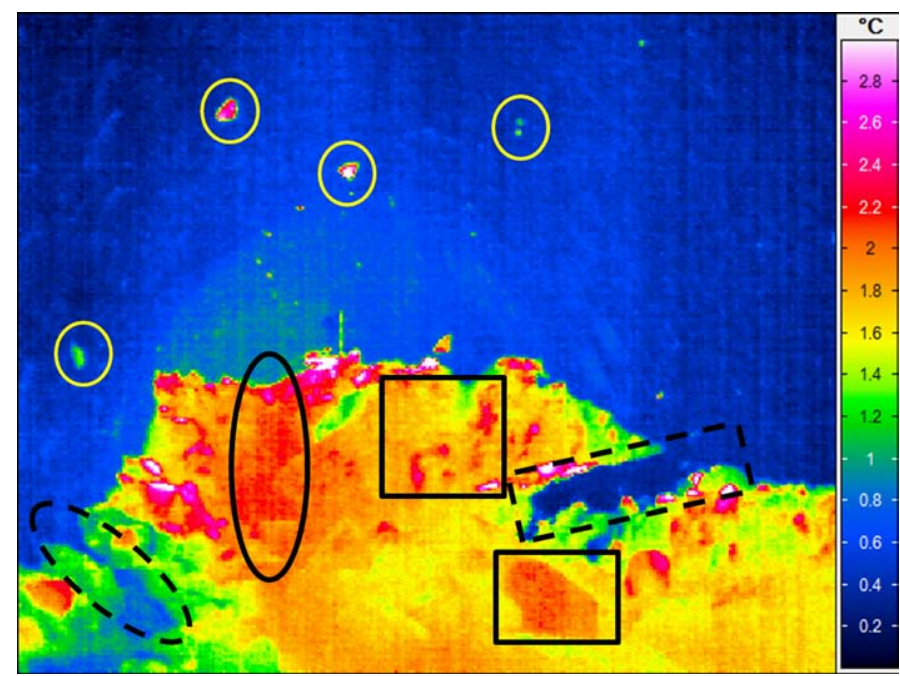

Figure 21. Thermal picture in Pure Imagination Cave in June 2015, facing upslope. The straight line in the back is the post of the ultrasonic anemometer. The warm spots in the blue ceiling and walls are rocks melting out the ice (yellow circles). White spots on the ground are mostly exposed and dry rocks. Purple and red spots on the ground are flowing water (black oval) or exposed rocks (black rectangle). The colder structures on the ground are cold meltwater (lighter blue with a dashed black oval) or solid ice (darker blue with a dashed black rectangle).

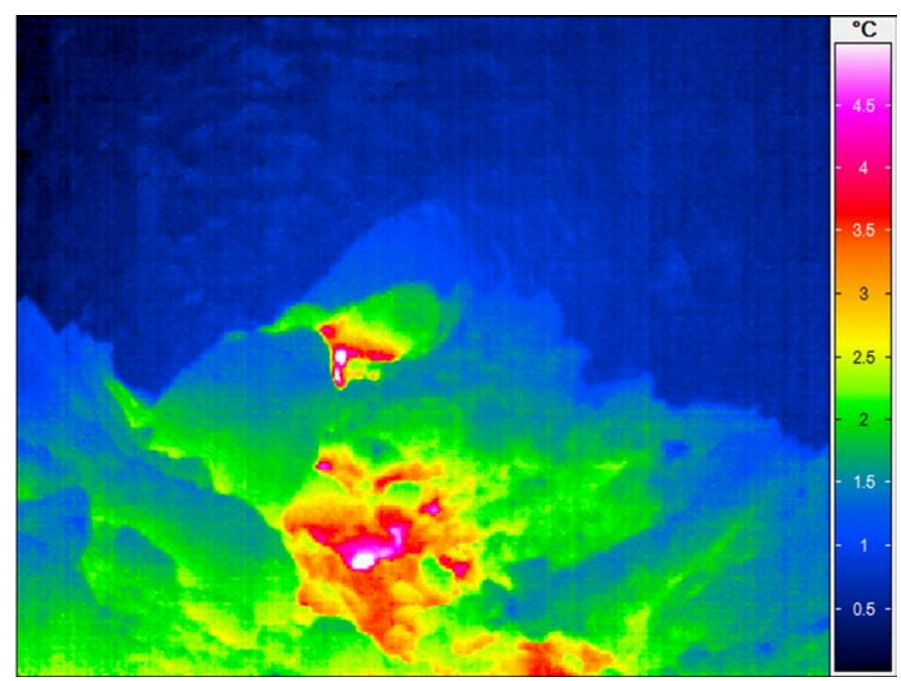

Figure 22. Thermal picture in Hot Imagination Cave in June 2015, facing upslope. The white and purple spots show clearly the warm water from the warm springs.

\section{Short-Term Measurements of Meltwater Using Sensor Chains and Thermal Cameras}

The first thermal images clearly indicated surprisingly high temperatures of out-flowing meltwater at the base of the glacier. While we found water temperatures of $1.6^{\circ} \mathrm{C}$ at the outlet at the lower entrance of the glacier at Pure Imagination Cave, those water temperatures increased to $7.7^{\circ} \mathrm{C}$ at the outlet in the higher area of Hot Imagination Cave to the moulin (Fig. 21).

However, at the outlet between ice mass and bedrock at the upper end of Hot Imagination Cave we found the expected meltwater temperature of exactly $0.0^{\circ} \mathrm{C}$. Because the sensor chain did not reach that far up and we were more interested in the temperature of the warm springs, these measurements were made a few times by hand-held devices.

A total of 46 warm springs in the out-flowing meltwater of the higher parts of the cave were identified by measurements using a thermal camera followed by direct measurements of water temperature using a temperature sensor (Figs. 22 to 24). Figure 22 shows an example of warm spots in the down-flowing meltwater streams. Figure 23, the series of four pictures shows the mixing of already warmed up meltwater with some warm, thermally-affected groundwater. These mixing areas can be found all over in Hot Imagination Cave. In the lower parts of the cave, only two warm springs were found (Fig. 24). Despite a continuous warming of the total meltwater flow, those springs could be clearly differentiated from surrounding water.

Figure 25 outlines the high variation range of water temperatures by showing data from twelve selected temperature sensors of the sensor chain. The largely unaffected meltwater shows stable temperatures slightly above freezing point. These water temperatures increase to 1.5 to $2.2^{\circ} \mathrm{C}$ only 20 meters after leaving the glacier. Several thermal images indicated that these temperatures correspond to those of the ice-free ground. Either the ground is warmed up by a deeper heat source, or there are unknown slightly effective warm springs upgradient.

In comparison to the meltwater leaving the glacier, temperature sensors in the water measured higher temperatures to a greater or lesser extent. The temperatures of the unaffected water were just above the freezing point; the warmest hot spots were up to $26^{\circ} \mathrm{C}$. In the mixing areas of warm and cold water, as well as the air, the temperature was above $3^{\circ} \mathrm{C}$.

Three additional hot spots showed water temperatures of 17.7 to $19.2{ }^{\circ} \mathrm{C}$. For all mentioned measuring sites, the course of the temperature is very stable, and slight variations can only be found at the warmest point. The measurement period, however, was only 44 hours. The sites in the mixing area between cold meltwater and warm springs showed much higher variations, with warmer and cooler periods without any temperature changes in meltwater and spring water (Fig. 25). As these periods last for several minutes or hours, they cannot be explained by short-term turbulences, but can be due to changes in flow conditions or diurnal meltwater water level changes.

So-called hot spots only occur in connection with water, but higher bedrock temperatures could be identified by using 

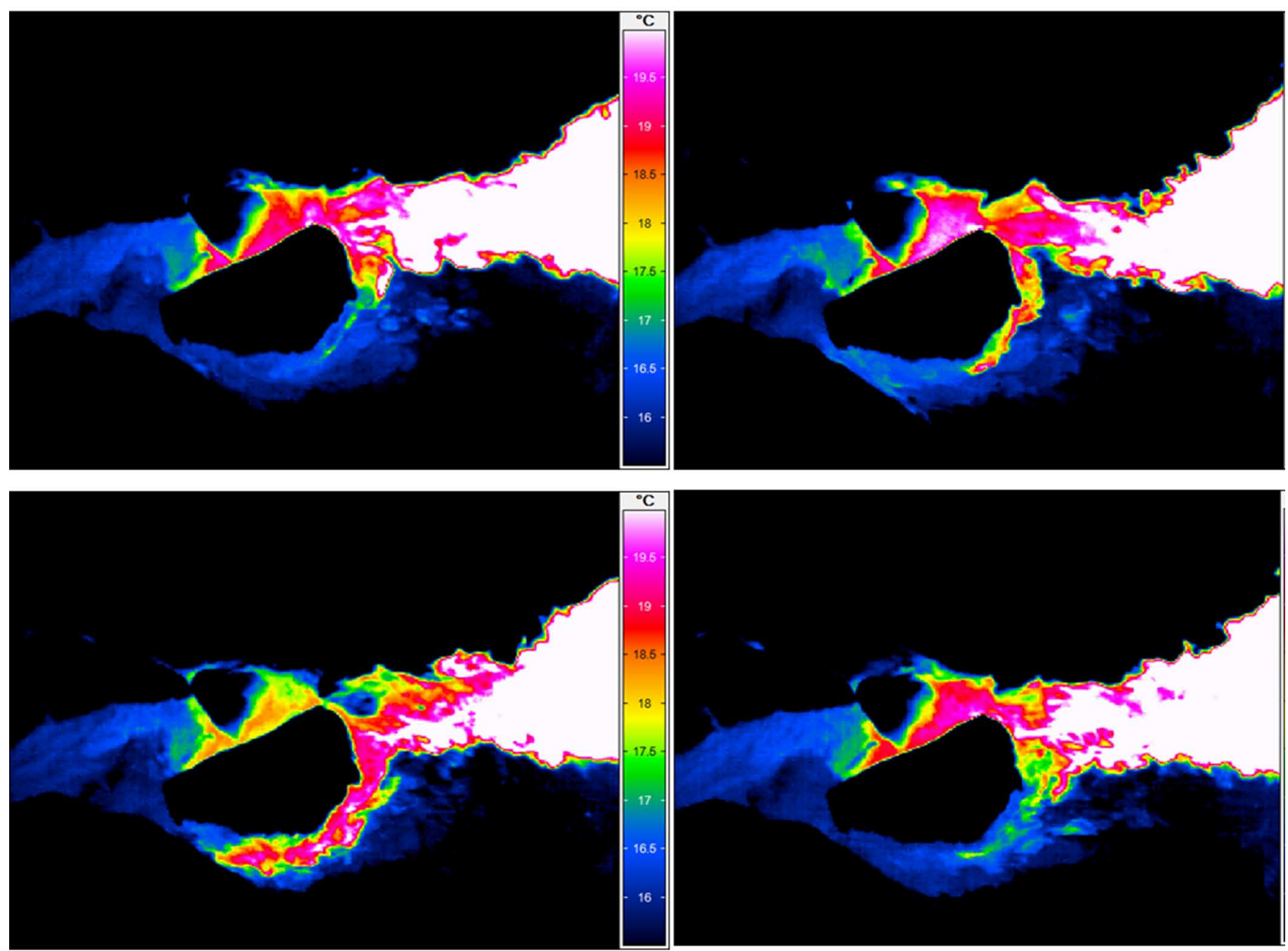

Figure 23. Series of thermal pictures documenting the mixing of already warm meltwater (blue) and warmer spring water (white) around a rock.

thermal cameras. However, those temperature changes of 1 to $3 \mathrm{~K}$ are relatively small and seem to be connected to warm springs below the surface (Figure 25). No fumaroles of hot steam could be identified.

\section{Short-Term Measurements of Air Temperature Using Sensor Chains}

With values of $4{ }^{\circ} \mathrm{C}$ to $5^{\circ} \mathrm{C}$, both sensors of the sensors chain measuring the air temperature in the upper part of Hot Imagination Cave, as well as the stationary data logger, found clearly increased temperature values. Those can be explained by the proximity of 0.2 to $0.5 \mathrm{~m}$ to warm springs. Although the consistently high air temperature is not expected inside a glacier cave, it can be explained by the thermal activity of the volcano.

\section{Short-Term Measurements of Surface Temperature Using Thermal Cameras}

The entire surface of the cave was surveyed twice each in the mornings of June 22, 2015 and June 24, 2015, using a thermal camera. The repeated survey reflected different external conditions characterized by steadily

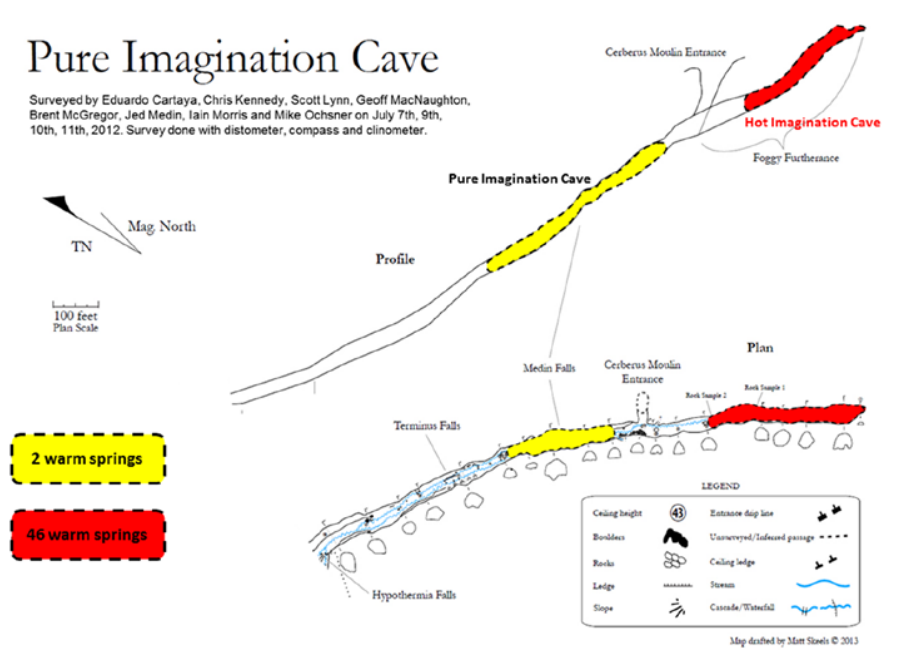

Figure 24. Areas with the numbers of proven warm springs in Pure and Hot Imagination Caves. 
increasing air temperatures. While the most important results in terms of warm spring areas have already been discussed in detail, further results will be presented below.

In general, the surface of the ice was covered with a thin film of water. Temperatures were around freezing point, with only temperatures of the transparent clear ice being lower. Those appeared as cold spots or bands in the thermal images.

Another important aspect regarding climatology of glacier caves is strongly warmed sediments of all grain sizes trapped in the ice (Fig. 26). Various sediments including long bands of clay, pebbles, and boulders with diameters of $1 \mathrm{~m}$ were identified, leading to numerous thermal patterns. An initial review of the thermal images shows a clear relation between sediment size and surface temperature, with larger sediment diameters being connected with stronger heating. Other important factors

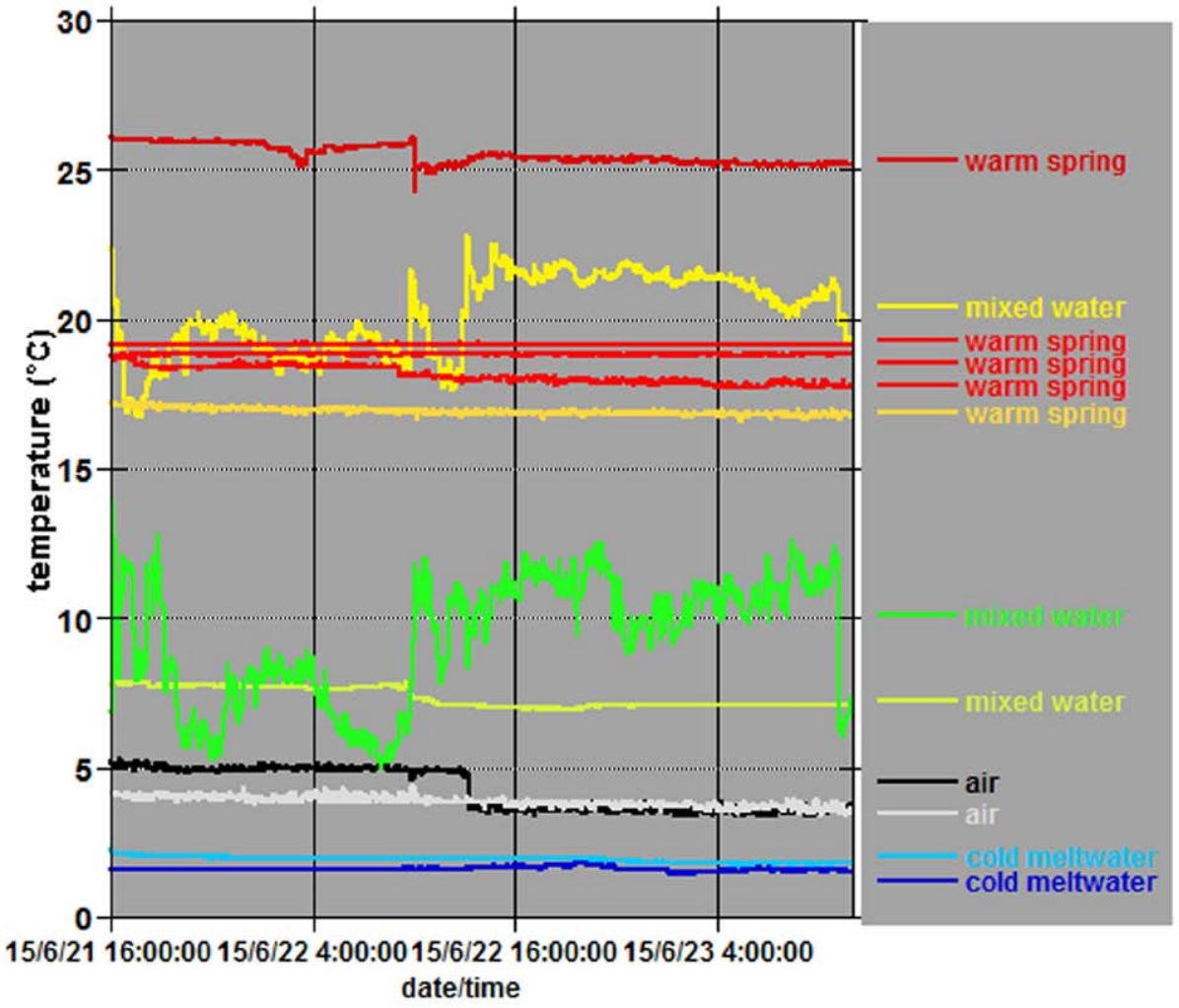

Figure 25. Air and water temperature at selected sensors of the sensor chain in Hot Imagination Cave from June 23 to June 25, 2015.

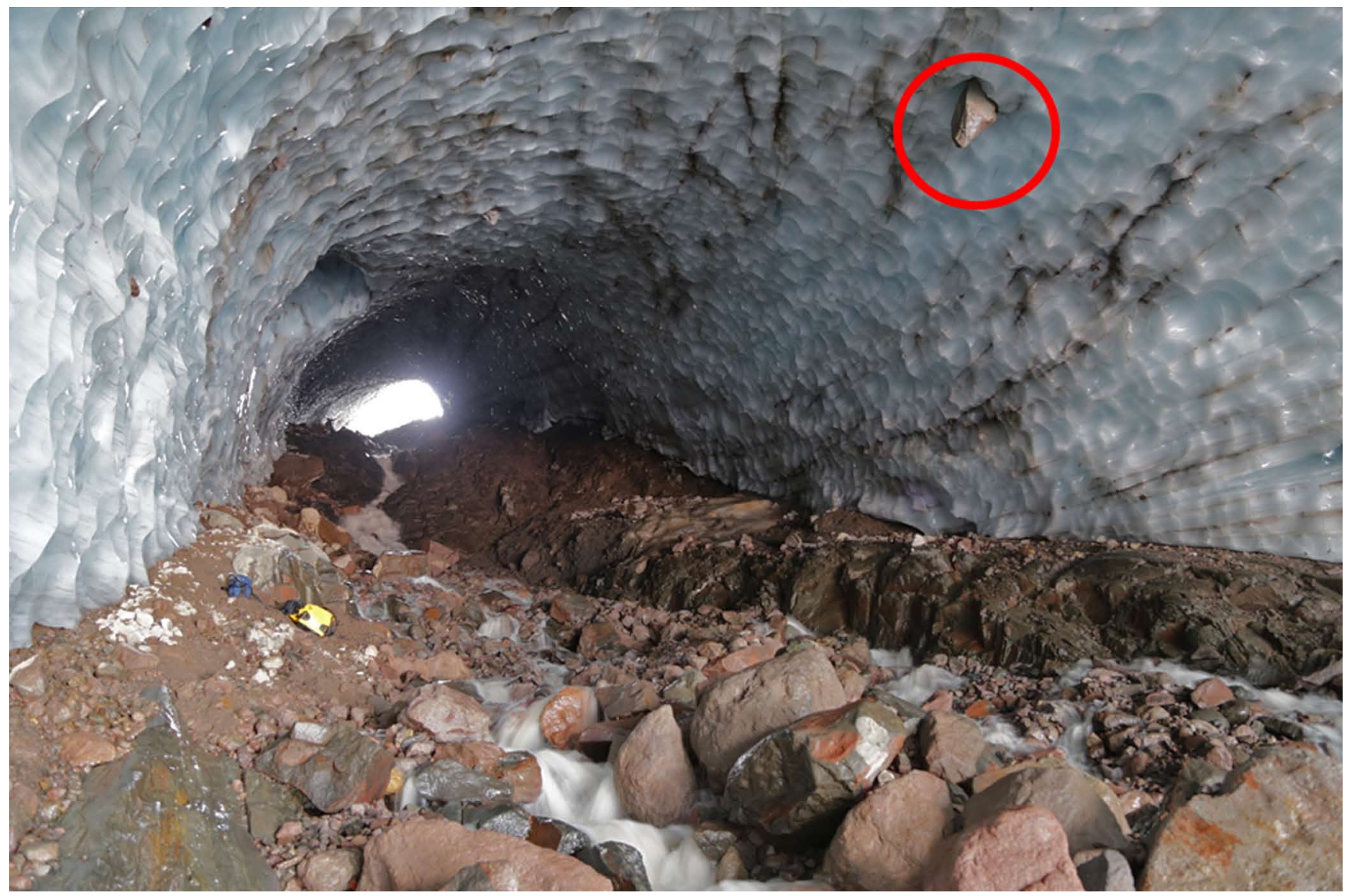

Figure 26. A boulder hanging in the ice ceiling of the cave and melting out. 
are the sediment's shape and the degree of melting around it. Rough boulders with exposed peaks and ridges warm more strongly than even and smooth surfaces. Rocks already melted from the ice and thus exposed to air currents also reached noticeably higher temperatures than rocks still mainly embedded in ice. Therefore, the melting of rocks out of ice is an accelerating process. Both the progressive warming of the rock, as well as its decreasing adhesion to the ice mass, lead to a fast detachment of the rock. Rocks in the ceiling detach faster than those in the wall, which experience some degree of support from underlying ice masses. The melting effect of large rocks also causes melting rings surrounding those boulders (Figs. 21 and 26 ).

Furthermore, the temperature of sediments largely depends on the temperature of air entering the glacier cave. During the first measurements on June 21 , we found rock temperatures of larger rocks $(>5 \mathrm{~cm})$ to be about 2.5 to $3.5^{\circ} \mathrm{C}$, with maximum temperatures of the largest rocks of $4.1^{\circ} \mathrm{C}$, whereas some days later those values increased to 4.0 to 5.0 ${ }^{\circ} \mathrm{C}$ with maximum of $6.0^{\circ} \mathrm{C}$ (Fig. 21). Unfortunately, we don't have enough measurements to give an exact correlation coefficient for the causal relationship between incoming air temperature, rock size, and rock temperature. Measurements to answer this important question are planned for future visits.

It can be assumed that the warming of ice up to freezing point continues, especially from exposed sediments. Consequently, ice close to warm rocks will melt faster than uninfluenced ice. However, it has to be considered that those results only reflect the situation during the summer months. In winter, rocks exposed from the ice may have the opposite effect: Atmospheric air below freezing entering the cave will first cool down those sediments, which conduct cold temperatures into the glacial ice body, leading to the formation of colder spots where the melting process of the glacier ice stops first.

\section{Measurements of Air Currents Using Ultrasonic Anemometers}

In addition to measurements of thermal events inside the glacier cave, investigations also focused on air currents.

Pure Imagination Cave (Figs. 27 and 28).

Unfortunately, the upper anemometer malfunctioned after 12:47 hours. But even the over the short period, the two instruments that measured the airflow simultaneously shows us remarkable result (Figs. 27 and 28). Some of us who have been inside a cave know strong winds caused by convection or barometric pressure effects very well (Pflitsch et al., 2010). But a combination of high airflow velocities and high temperatures inside a glacier cave as a mostly frozen environment had not been observed or measured yet.

In accordance with the high temperatures of the external atmosphere, which exceed the temperatures inside the tunnel for the entire measuring period, our measurements show a pronounced downward air current over the entire vertical distance of the tunnel for the entire measuring period. Warm air enters through the moulin, cools down, flows downward due to gravity, and leaves the tunnel through the lower opening. This result is consistent with investigations during the individual measurements.

The flow velocities reached $4.04 \mathrm{~m} \mathrm{~s}^{-1}$ close to the ground and $6.68 \mathrm{~m} \mathrm{~s}^{-1}$ close to the ceiling at the same time. Even the mean values of the horizontal component of $1.55 \mathrm{~m} \mathrm{~s}^{-1}$ at ground-level and $3.14 \mathrm{~m} \mathrm{~s}^{-1}$ at the ceiling show relatively high values, with an increase of velocity with increasing height above ground. This effect might be caused by the higher roughness of the ground and is typical for the outside atmosphere as well. Similarly, on average, the vertical components of $0.72 \mathrm{~m} \mathrm{~s}^{-1}$ and $-1.28 \mathrm{~m} \mathrm{~s}^{-1}$ indicate a clear downward movement. Further values are included in Tables 1 and

Table 1. Statistical overview about the measurements of the ultrasonic anemometer in Pure Imagination Cave $(v=$ horizontal air velocity $\left(\mathrm{m} \mathrm{s}^{-1}\right), \mathrm{z}=$ vertical air velocity $\left(\mathrm{m} \mathrm{s}^{-1}\right), \mathrm{t}=$ air temperature $\left.\left({ }^{\circ} \mathrm{C}\right)\right)$.

\begin{tabular}{lcccccc}
\hline Statistic & v-ground & v-ceiling & z-ground & z-ceiling & t-ground & t-ceiling \\
\hline min & 0 & 0 & -0.32 & -0.38 & 2.32 & 2.34 \\
max & 0.88 & 1.24 & 0.52 & 0.41 & 4.87 & 5.99 \\
average & 0.3 & 0.48 & 0.04 & 0.03 & 3.57 & 3.6 \\
median & 0.3 & 0.48 & 0.4 & 0.03 & 3.59 & 3.62 \\
variance & 8.64 & 24.02 & 2.42 & 3.8 & 12.78 & 20.95 \\
\hline
\end{tabular}

Table 2. Statistical overview about the measurements of the ultrasonic anemometer in Hot Imagination Cave ( $v=$ horizontal air velocity $\left(\mathrm{m} \mathrm{s}^{-1}\right), \mathrm{z}=$ vertical air velocity $\left(\mathrm{m} \mathrm{s}^{-1}\right), \mathrm{t}=$ air temperature $\left.\left({ }^{\circ} \mathrm{C}\right)\right)$.

\begin{tabular}{|c|c|c|c|c|c|c|c|c|c|}
\hline Statistic & $\begin{array}{c}\text { v-ground, } \\
\text { short }\end{array}$ & $\begin{array}{l}\text { v-ground, } \\
\text { long }\end{array}$ & v-ceiling & $\begin{array}{c}\text { z-ground, } \\
\text { short }\end{array}$ & $\begin{array}{l}\text { z-ground, } \\
\text { long }\end{array}$ & z-ceiling & $\begin{array}{l}\text { t-ground, } \\
\text { short }\end{array}$ & $\begin{array}{l}\text { t-ground, } \\
\text { long }\end{array}$ & t-ceiling \\
\hline $\max$ & 4.04 & 4.75 & 6.68 & 0.34 & 1.12 & 0.87 & 11.19 & 12.77 & 13.23 \\
\hline median & 1.71 & 1.85 & 3.1 & -0.71 & -0.83 & -1.26 & 8.03 & 8.77 & 9.51 \\
\hline variance & 17.96 & 26.89 & 48.49 & 6.7 & 9.71 & 14.46 & 78.17 & 126.49 & 80.09 \\
\hline
\end{tabular}




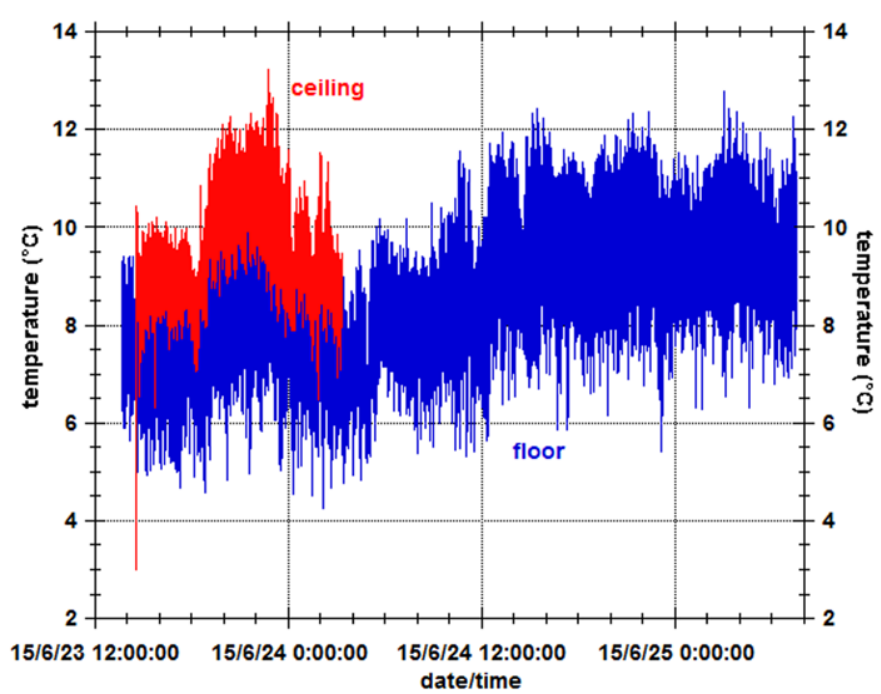

Figure 27. Air temperature $\left({ }^{\circ} \mathrm{C}\right)$ of airflow at $0.6 \mathrm{~m}$ and $4.5 \mathrm{~m}$ above ground in Pure Imagination Cave from June 23, 2015 to June 25, 2015.

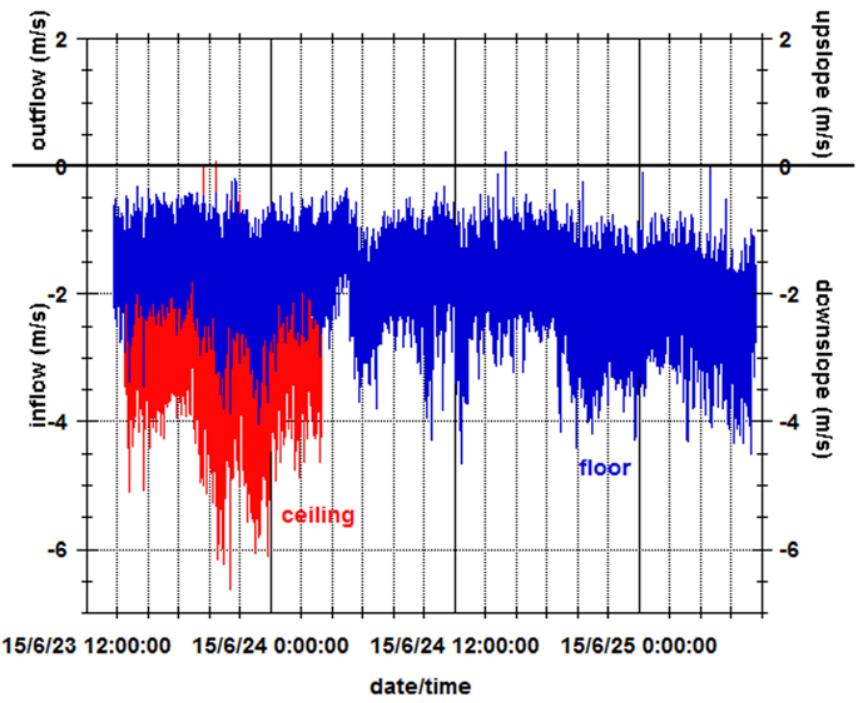

Figure 28. Direction and velocity $\left(\mathrm{m} \mathrm{s}^{-1}\right)$ of airflow at $0.6 \mathrm{~m}$ and 4.5 $\mathrm{m}$ above ground in Pure Imagination Cave from June 23 to June 25,2015 .

\section{2.}

The temperatures of the cave air are quite surprising as well, reaching $4.3^{\circ} \mathrm{C}$ to $11.2^{\circ} \mathrm{C}$ at ground level just above the glacier water and $6.3^{\circ} \mathrm{C}$ to $13.2^{\circ} \mathrm{C}$ close to the ceiling for the corresponding12 hour time period. Also, the mean values of $8.1^{\circ} \mathrm{C}$ close to the ground and $9.6^{\circ} \mathrm{C}$ close to the ceiling show a clear temperature increase with height in the glacier tunnel. Those high air temperatures inside the ice tunnel are no snapshots, as proven by a further increase in temperature measured at ground level over the entire measurement period.

Hot Imagination Cave (Figs. 29 and 30)

Completely different flow conditions were found above the moulin in Hot Imagination Cave, the upper end of which, is closed (Fig. 15). Both horizontal and vertical flow velocities are lower. Thus for the area close to the ceiling, the maximum of the horizontal component was only $1.24 \mathrm{~m} \mathrm{~s}^{-1}$ with a mean value of $0.48 \mathrm{~m} \mathrm{~s}^{-1}$, whereas for the area close to the ground maximum and mean values of only $0.88 \mathrm{~m} \mathrm{~s}^{-1}$ and $0.3 \mathrm{~m} \mathrm{~s}^{-1}$ respectively were found. The vertical component, with mean values of 0.03 and $0.04 \mathrm{~m} \mathrm{~s}^{-1}$ and maximum values of less than $\pm 0.5 \mathrm{~m} \mathrm{~s}^{-1}$, was very weak compared to the dynamic part of the glacier tunnel. The flow rates inside the upper closed part of the glacier cave seem inconsiderable compared to the lower part with openings on both sites. These flow rates, however, are still higher than those of many other known static and even dynamic caves. (Pflitsch et al., 2010) The flow direction reveals a clearly pronounced vertically structured flow system in this part of the glacier cave. Thus for the area close to the ground, a clear and steady outflow was found, while air was flowing in upwards along the ceiling.

Taking the temperature information measured by sonics into account, it can be summarized that at least temporarily, ground-level cold air flows out of the cave while warm air flows in at the ceiling. During warm periods, the air temperatures close to the ceiling are higher than those close to the ground, while during cooler periods, the air close to the ceiling is cooler than at ground level. Thus on average, both areas appear equally tempered, with mean values of around $3.6^{\circ} \mathrm{C}$. However, the maximum temperatures of $4.9^{\circ} \mathrm{C}$ close to the ground and $6.0^{\circ} \mathrm{C}$ close to the ceiling differ clearly.

The origin of warm air currents close to the ceiling could not be determined yet. During warmer periods, warm air from the outside might accumulate underneath the ceiling, while during colder periods "waste heat" from the water might have an effect and heat layers of air close to the ground. The former is rather unlikely, as air masses from the outside of the tunnel cannot enter this part of the cave easily due to the moulin's shape and the relatively small opening to the upper area. In addition, there is no dynamic drive by the suction effect as found in the lower part of the cave. The relatively small temperature difference between the air close to the ground and close to the ceiling and the rather turbulent vertical and horizontal air movements suggest convective mixing of air. It might be caused by the warm water. This is also supported by sections with weak air movements where temperature peaks in the higher air layers correspond with temperature decreases close to the ground and vice versa.

In addition, a recently developing Drooling Moulin $10 \mathrm{~m}$ up-glacier away from the measurement site at least temporarily influences the vertical component of the flow regime. This moulin, which had already been observed in the previous year, but closed during the winter months, generates waterfall-like dripping meltwater. The rate of meltwater 


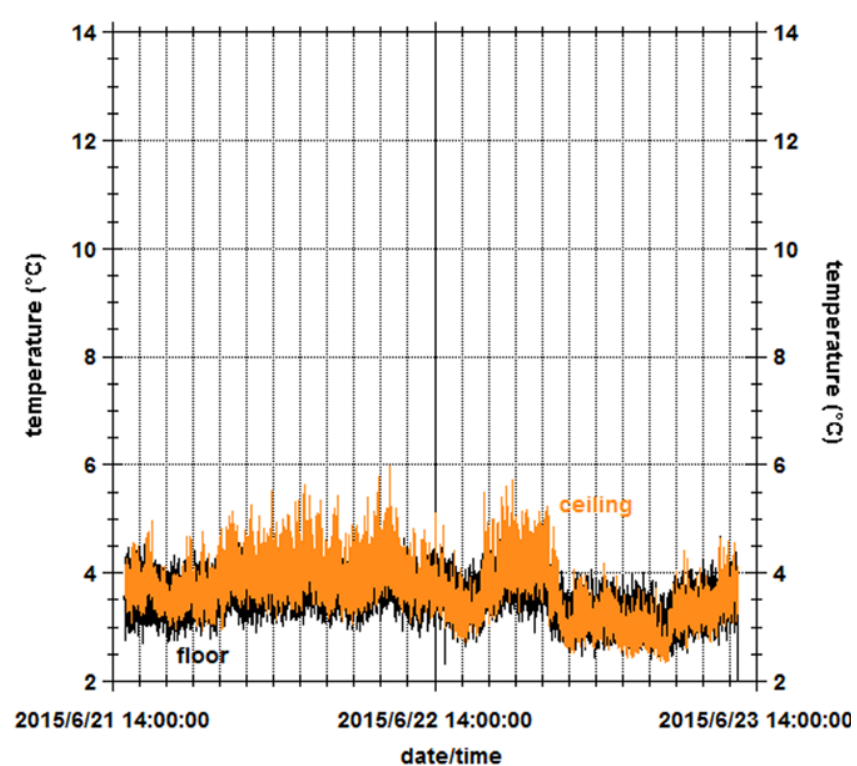

Figure 29. Air temperature $\left({ }^{\circ} \mathrm{C}\right)$ in Hot Imagination Cave at $0.6 \mathrm{~m}$ and $4.5 \mathrm{~m}$ above ground from June 23, 2015 to June 25, 2015.

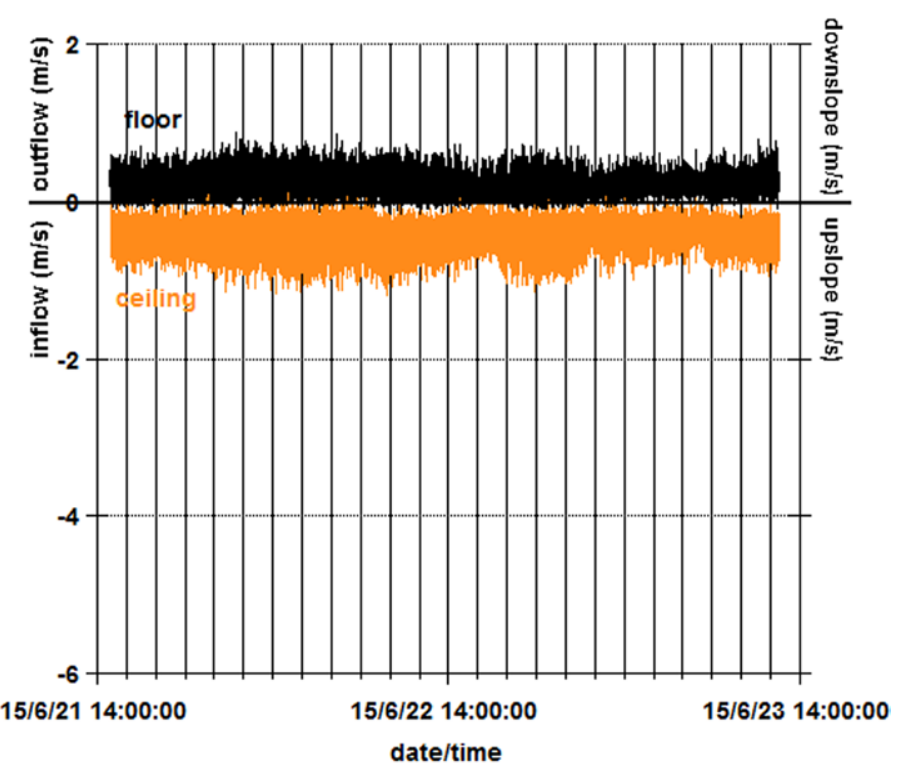

Figure 30. Direction and velocity $\left(\mathrm{m} \mathrm{s}^{-1}\right)$ of airflow in Hot Imagination Cave at $0.6 \mathrm{~m}$ and $4.5 \mathrm{~m}$ above ground from June 23, 2015 to June 25, 2015.

dripping reached its maximum in the afternoon, while being weaker at night. Measurements by smoke tubes (Draeger Air Current tubes) show that in the area of dripping meltwater ,cold air is carried downwards before rising to the sides like a reverse mushroom shape similar to a downburst. Here impulses of air movement were induced by both falling water masses dragging the air downwards as well as the gravitational descent of air cooled by the water. At the edge of this "micro downburst," turbulence leading to mixing of air layers close to the ground with those close to the ceiling could be repeatedly observed. This observation could not be confirmed by measurements.

\section{Additional Observations}

In the area of centrally out-flowing water, and especially above warm springs, the lower layers of air show a higher air temperature than that in other areas. The warmed air rises in the center of the cave and collects immediately below the ceiling. Afterwards, it cools down and sinks at the cave walls. This was proven using smoke tubes. However, we found an asymmetry of both halves of the cave. In the upper end of the cave, the right half showed a general tendency of air rising toward the upper end, whereas air in the left half of the cave tended to sink toward the lower entrance of the cave. We think this is a spiral or corkscrew-like convection process caused by the downslope-flowing cold air, upslope-flowing warm air, and down-flowing cold air from the ceiling disturbed by the relatively warm meltwater and springs.

\section{Summary of Measuring Results}

The first expedition to Mt. Hood with a focus on investigating the climatological condition inside Sandy Glacier brought us an enormous amount of new results for understanding the glacier. The results are summarized as follows.

Substantially increased air temperatures measured during previous expeditions were confirmed both by stationary long-term and mobile short-term measurements. By using thermal cameras, we could also find reasons for those unusually high air temperatures. High air temperatures in the upper part of the cave are caused by numerous warm springs with water temperatures up to $26^{\circ} \mathrm{C}$. The water, however, is not only heated at those specific spots, but lastingly. Warm springs cause a constant warming of the water up to $7.7^{\circ} \mathrm{C}$ up to the Cerebus Moulin and $1.6^{\circ} \mathrm{C}$ to the lower entrance. Consequently, increased water temperatures lead to an increase of air temperature.

Another phenomenon of the central and upper areas of Hot Imagination Cave is the constant formation of fog, which forms by the mixing of rising warm and humid air masses from the warm meltwater areas and the cooler air masses from the ice walls of the cave.

In the lower part of the cave, warm water that cools due to in flowing meltwater and is warmed to a lesser extent by two warm springs, plays a tangential role enlarging the cave. In this part, the cave's large cross-sectional area and the large upper opening of the moulin and the lower entrance are more important for melting processes inside the cave. Both openings lead to strong chimney-effect currents between the external atmosphere and the air inside the cave, causing warm air masses from the outside to enter the cave. This was proven using ultrasonic measurements.

Warm air causes both, direct melting of the ice walls and a strong warming of rocks and sediments that are embed- 
ded in the ice. Heating of those rocks accelerates the melting of surrounding ice masses, with large boulders causing additional heat flow into the first few meters of glacial ice.

Formation of glacier caves over an area of geothermal heat is a self-reinforcing process. Warm springs cause the formation of caves, leading to unusually large glacier caves with large openings that allow warm atmospheric air to enter the cave and accelerate further melting.

\section{Important Activities for Future Research}

It is clear that Sandy Glacier is located above an active volcano, with warm springs below the glacier. But even without the power of geothermal processes, inside glacial conduits or caves with a chimney effect, especially in regions with summer temperatures above the freezing point, the cave's climate is important to take into account for glacier melting. We have to take into account that these caves can play a substantial role in the mass balance and energy balance of a glacier. Especially at the lower part of the glacier, the ablation zone, glacier caves with a rocky floor (contact caves) can have a large effect to interior melting. In these parts, the rocky floor does warm up by direct and indirect sunlight and inflowing warm air masses. Convective upslope warm air and longwave radiation from the rocky floor and walls move energy though the interior of the glacier or ice pack and intensify melting processes. The thinning of the glacier cave ceilings can lead to unexpected collapses of up to hundred meters of cave in one summer and accelerate the glacier retreat enormously. An example is Worthington Glacier in Alaska near Valdez. We visited the glacier for about six years and the south-facing tongue showed always a glacier cave at the morning-sun-facing side, at least when the sun was high enough. The opposite side gets most of the year no sun. At the sun-facing side the glacier is for about 10 to $30 \mathrm{~m}$ (depends on the season, not attached to the open bedrock, and the cave, building between the glacier and the bedrock, has an unstable ceiling with many collapses. Thermal investigations showed already the warmer bedrock in comparison to the colder ice. Unfortunately, no further investigations have been done yet.

We know that these are the first results of a new field of research and there is a lot more work to do. Further expeditions are in preparation to observe the glacier and its caves, intensify and expand the measurements as a good base for necessary calculations. Future expeditions to Mt. Hood, Mt. St. Helens, and Mount Rainier are planned. Additionally, we have to expand this research to glaciers that are not affected by thermal heat sources, but with some good summer heat and a strong retreat like in Alaska, the Alps, or southern Greenland, to confirm our theories.

\section{Acknowledgements}

We acknowledge the help of the numerous porters who carried all the equipment and instrumentation, as well as food, up to base camp and then helped pack our gear back down the mountain to the trail head. Also the cavers who surveyed and mapped the cave and the photographers that documented the expedition. Without the multiple skills of the team members, the work could not have progressed.

\section{References}

Aizen, V., 2011, High Elevation Glazio Climatology, in Singh, V.P., Singh, P., and Haritashyya, U.K., ed., Encyclopedia of Snow, Ice and Glaciers (Encyclopedia of Earth Sciences Series): Dordrecht, Springer Science \& Business Media B.V., p. 507-510. https://doi.org/10.1007/978-90-4812642-2_671.

Alean, J., 2010, Gletscher der Alpen (first edition): Bern Stuttgart Wien, Haupt Verlag, 267 p.

Andrews, L.C., Catania, G.A., Hoffmann, M.J., Gulley, J.D., Lüthi, M.P., Ryser, C., Hawley, R.L., and Neumann, T.A., 2014, Direct observations of evolving subglacial drainage beneath the Greenland Ice Sheet: Nature, v. 514, p. 80-83. https://doi.org/10.1038/nature13796.

Badino, G.,De Vivo, A., and Piccini, L., 2007, Caves of Sky, the Journey in the Heart of Glaciers. Tintoretto, 153 p.

Barry, R., and Gan, T.Y., 2011, The Global Cryosphere: Past, Present and Future (first edition): Cambridge, Cambridge University Press, 498 p. Benn, D., and Evans, D. J., 2010, Glaciers and Glaciations (second edition): London, Routledge, 816 p.

Bhutiyani, M.B., 2011, Ice Caves, in Singh, V.P., Singh, P., and Haritashya, U.K., ed., Encyclopedia of Snow, Ice and Glaciers (Encyclopedia of Earth Sciences Series): Dordrecht, Springer Science \& Business Media B.V., p. 583-584.

Blockley, S.P.E., Bourne, A.J., Brauer, A., Davies, S.M., Hardiman, M., Harding., P.R., Lane, C.S., MacLeod, A., Matthews, I.P., Pyne-O'Donnell, S.D.F., Rasmussen, S.O., Wulf, S., and Zanchetta, G., 2014, Tephrochronology and the extended intimate (integration of ice-core, marine and terrestrial records) event stratigraphy 8-128 ka b2k: Quaternary Science Reviews, v. 106, p. 88-100. https://doi.org/10.1016/ j.quascirev.2014.11.002.

Bourne, A.J., Cook, E., Abbott, P.M., Seierstad, I.K., Steffensen, J.P., Svensson, A., Fischer, H., Schüpbach, S., and Davies, S.M., 2015, A tephra lattice for Greenland and a reconstruction of volcanic events spanning 25-45 ka b2k: Quaternary Science Reviews, v. 118, p. $122-141$. https://doi.org/10.1016/j.quascirev.2014.07.017.

Brugman, M.M. and Post, A. 1981, Effects of Volcanism on the Glaciers of Mount St. Helens: U.S. Geological Survey Circular $850-D, 11$ p.

Fountain, A.G., 2011, Englacial Processes, in Singh, V.P., Singh, P., and Haritashya, U.K., ed., Encyclopedia of Snow, Ice and Glaciers (Encyclopedia of Earth Sciences Series): Dordrecht, Springer Science \& Business Media B.V., p. 258-261. https://doi.org/10.1007/978-90-481-26422_135.

Fountain, A.G., Jacobel, R.W., Schlichting, R., and Jansson, P., 2005, Fractures as the main pathways of water flow in temperate glaciers: Nature, v. 433, p. 618-621. https://doi.org/10.1038/nature03296.

Greenwood, S.L., Clason, C.C., Helanow, C., and Margold, M., 2016, Theoretical, contemporary observational and palaeo-perspectives on ice sheet hydrology: Processes and products: Earth-Science Reviews, v. 155, p. 1-27. https://doi.org/10.1016/j.earscirev.2016.01.010.

Gunn, J., 2004, Encyclopedia of Caves and Karst Science (second edition): New York, Taylor \& Francis, 960 p. 
Holmlund, P., 1988, Internal geometry and evolution of moulins: Storglaciären, Sweden: Journal of Glaciology, v. 34, n. 117, p. $242-248$.

Lauritzen, S.-E., 1981, Statistical Symmetry Analysis of Scallops: NSS Bulletin, v. 43, p. 52-55.

Leonard, K.C., 1835, Lehrbuch der Geognosie und Geologie (Band 1): Stuttgart, Schweizerbart's Verlagshandlung, 873 p.

Pflitsch, A., Schörghofer, N., Smith, S.M., and Holmgren, D., 2016, Massive ice loss from the Mauna Loa Icecave, Hawaii: Arctic, Antarctic, and Alpine Research, v. 48, no. 1, p. 33-43.

Pflitsch, A., Willes, M., Horrocks, R. Piasecki, J. and Ringeis, J., 2010, Dynamik climatologic processes of barometric cave systems using the example of Jewel Cave and Wind Cave in South Dakota, USA, Acta Carsologica, v. 39, no. 3, p. 449-462.

Rhodes, R.H., Faïn, X., Brook, E.J., McConnell, J.R., Maselli, O.J., Sigl, M., Edwards, J., Buizert, C., Blunier, T., Chappellaz, J., and Freitag, J., 2016, Local artifacts in ice core methane records caused by layered bubble trapping and in situ production: a multi-site investigation: Climate of the Past, v. 12, p. 1061-1077. https://doi.org/10.5194/cp-12-1061-2016.

Schroeder, J., 2007, Moulins of a subpolar glacier seen as a thermal anomaly, in Tyc, A., and Stefaniak, K., eds., Karst and Cryokarst: Joint Proceedings of the 25th Speleological School and 8th International GLACKIPR Symposium, p. 65-74.

Sigl, M., Fudge, T.J., Winstrup, M., Cole-Dai, J., Ferris, D., McConnell, J.R., Taylor, K.C., Welten, K.C., Woodruff, T.E., Adolphi, F., Bisaux, M., Brook, E.J., Buizert, C., Caffee, M.W., Dunbar, N.W., Edwards, R., Geng, L., Iverson, M., Koffman, B., Layman, L., Maselli, O.J., McGwire, K., Muscheler, R., Nishiizumi, K., Pasteris, D.R., Rhodes, R.H., and Sowers, T.A., 2016, The WAIS Divide deep ice core WD2014 chronology - Part 2: Annual-layer counting (0-31kaBP): Climate of the Past, v. 12, p. 769-786. https://doi.org/10.5194/cp-12-769-2016.

Singh, V.P., Singh, P., and Haritashyya, U.K., 2011, Encyclopedia of Snow, Ice and Glaciers (Encyclopedia of Earth Sciences Series): Dordrecht, Springer Science \& Business Media B.V., 1253 p.

Sugden, D.E. and John, B. C., 1976, Glacier and Landscape: A Geomorphological Approach: London, Edward Arnold, 376 p.

Unterfrauner, L., 2009, Investigation of Water Storage and Flow Processes in Snow, Firn and Ice: A glacial-hydrological Investigation on the Alpine Glacier Goldbergkees in the Sonnblick Region (Hohe Tauern, Salzburg, Austria) [Diploma Thesis]: Wien, Universität Wien, 136 p.

Vihma, T., 2011, Atmospheric-Snow/lce Interactions, in Singh, V.P., Singh, P., and aritashyya, U.K., ed., Encyclopedia of Snow, Ice and Glaciers (Encyclopedia of Earth Sciences Series) Dordrecht, Springer Science \& Business Media B.V., p. 507-510. https://doi.org/10.1007/978-90-4812642-2_31. 